OPEN ACCESS

Edited by:

Patrick McGowan,

University of Toronto, Canada

Reviewed by: Gerd Peter Pfeifer,

Van Andel Institute, United States Maurizio D'Esposito, Consiglio Nazionale delle Ricerche

(CNR), Italy

${ }^{*}$ Correspondence:

Ramiro Alberio

ramiro.alberio@nottingham.ac.uk

Specialty section:

This article was submitted to Epigenomics and Epigenetics,

a section of the journal

Frontiers in Cell and Developmental

Biology

Received: 20 November 2017 Accepted: 27 February 2018

Published: 27 March 2018

Citation:

Zhu Q, Stöger R and Alberio R (2018) A Lexicon of DNA Modifications: Their Roles in Embryo Development and the Germline. Front. Cell Dev. Biol. 6:24. doi: 10.3389/fcell.2018.00024

\section{A Lexicon of DNA Modifications: Their Roles in Embryo Development and the Germline}

\author{
Qifan Zhu, Reinhard Stöger and Ramiro Alberio* \\ School of Biosciences, University of Nottingham, Nottingham, United Kingdom
}

5-methylcytosine ( $5 \mathrm{mC}$ ) on $\mathrm{CpG}$ dinucleotides has been viewed as the major epigenetic modification in eukaryotes for a long time. Apart from $5 \mathrm{mC}$, additional DNA modifications have been discovered in eukaryotic genomes. Many of these modifications are thought to be solely associated with DNA damage. However, growing evidence indicates that some base modifications, namely 5-hydroxymethylcytosine $(5 \mathrm{hmC}), 5$-formylcytosine (5fC), 5-carboxylcytosine (5caC), and N6-methadenine $(6 \mathrm{~mA})$, may be of biological relevance, particularly during early stages of embryo development. Although abundance of these DNA modifications in eukaryotic genomes can be low, there are suggestions that they cooperate with other epigenetic markers to affect DNA-protein interactions, gene expression, defense of genome stability and epigenetic inheritance. Little is still known about their distribution in different tissues and their functions during key stages of the animal lifecycle. This review discusses current knowledge and future perspectives of these novel DNA modifications in the mammalian genome with a focus on their dynamic distribution during early embryonic development and their potential function in epigenetic inheritance through the germ line.

Keywords: modified bases in eukaryotic DNA, $5 \mathrm{mC}, 5 \mathrm{hmC}, 6 \mathrm{~mA}$, germ cells, embryo, epigenetic reprogramming

\section{INTRODUCTION}

5-methylcytosine $(5 \mathrm{mC})$ in CpG dinucleotides is the most abundantly modified DNA base in eukaryotes. Its role as an epigenetic regulator of gene expression has been widely studied and documented (Holliday and Pugh, 1975; Riggs, 1975; Sager and Kitchin, 1975; Bird and Wolffe, 1999; Bird, 2002; Robertson, 2005; Jones, 2012; Smith and Meissner, 2013; Edwards et al., 2017). However, DNA modifications are much more diverse than previously thought. Apart from $5 \mathrm{mC}$, nearly 40 verified and many more unverified DNA modifications can be found in a newly established DNA modification Database (Sood et al., 2016). Novel approaches have been suggested for systematic detection (Thiaville et al., 2016) and computational identification (Iyer et al., 2013) of novel epigenetic marks in prokaryotes, of which the strategies could also be applied to eukaryotic genomes. Most of the DNA modifications are indicators of DNA damage and related to DNA repair pathways (Ito and Kuraoka, 2015), but they have not yet been correlated with other biological processes. Studies in the last few years provide growing evidence for biological significance of some DNA modifications, including 5-hydroxymethylcytosine $(5 \mathrm{hmC}), 5$-formylcytosine $(5 \mathrm{fC})$, 5-carboxylcytosine $(5 \mathrm{caC})$, 5-hydroxymethyluracil $(5 \mathrm{hmU})$, and N6-methadenine $(6 \mathrm{~mA})$. With recently suggested biological potentials, these DNA base variants are considered as 'novel DNA modifications'. The rareness and instability of these novel DNA modifications in eukaryotic 
genomes are the major obstacles for studying their potential functions. Because of these features, most of the aforementioned novel modifications were considered to be intermediates of DNA demethylation processes, and doubts have been cast on whether they are abundant or sufficiently stable to have significant effects on biological processes. Whether and how these novel DNA modifications can be stably maintained through cell division and during differentiation is largely unknown. Still, these modifications have been suggested to cooperate with histone modifications and thereby affect the epigenome at specific loci. They also affect the structure and accessibility of DNA, which in turn regulates DNA-protein interactions, gene expression and genome stability. Although little is known about their distribution, their turnover and their functions, these novel DNA modifications show highly temporal and spatially restricted profiles. For example, $6 \mathrm{~mA}$ shows significant but transient enrichment in early embryogenesis of zebrafish and pig, with a maximum of $\sim 0.1 \% 6 \mathrm{~mA} / \mathrm{A}$ in 32 -cell to 64 -cell embryo stage in zebrafish and $\sim 0.17 \%$ in pig 4 -cell to morula stage, but only $0.006 \%$ in zebrafish 512 -cell stage and $0.05 \%$ in pig blastocyst (Liu J. et al., 2016). Distributions and regulatory mechanisms of DNA modifications also differ greatly among species (Law and Jacobsen, 2010; He Y.-F. et al., 2011). For example, compared to mammalian genomes, a higher proportion (over $30 \%$ ) of $5 \mathrm{mC}$ in plant genomes is located within non-CG sites (Vanyushin and Ashapkin, 2011), whereas C. elegans and D. melanogaster genomes are largely devoid of $5 \mathrm{mC}$ (Capuano et al., 2014). Similar to other well-studied epigenetic marks, novel DNA modifications are highly dynamic during the two waves of global epigenetic reprogramming at early embryonic stages in mammals. However we still know very little about their roles during these events. This review will discuss the current knowledge and future perspectives of these novel DNA modifications as well as $5 \mathrm{mC}$, with a focus on their profiles and potential biological function in early embryonic development and the germline in mammals.

\section{5mC AND TET-MEDIATED ACTIVE DEMETHYLATION IN EARLY DEVELOPMENT}

The presence of 5-methylcytosine in DNA (5mC) was first reported in mammals in the late 1940s and its role in epigenetic regulation of gene expression has been widely studied and documented (Jones, 2012; Plongthongkum et al., 2014; Breiling and Lyko, 2015). The functions of $5 \mathrm{mC}$ in early development are mainly revealed via studies of $5 \mathrm{mC}$ distribution and activities of its modifiers in embryonic stem cells (ESCs). $5 \mathrm{mC}$ in promoter regions - upstream of transcription start sites (TSS) and transposable elements, is generally considered as a silencing mark for gene expression, while the regulatory role of $5 \mathrm{mC}$ on gene bodies for gene expression remains unclear (Jones, 2012; Kim et al., 2014; Chen et al., 2016; Hargan-Calvopina et al., 2016). DNA methylation at distal regulatory elements, such as embryonic stem cell (ES)-specific enhancers and insulators, has also been suggested to correlate with gene expression (Hon et al., 2013; Aran et al., 2016; Heyn et al., 2016) as well as with the activities of transcriptional regulators (Stadler et al., 2011; Wang et al., 2012; Maurano et al., 2015; Aran et al., 2016; Hnisz et al., 2016). For example, triple-knockout (TKO) of Tet (Teneleven translocation) enzymes, the $5 \mathrm{mC}$ 'editors', in mouse ESCs (mESCs) results in increased DNA methylation mainly at distal enhancer regions coupled with changed expression of linked genes, suggesting that Tet-dependent active demethylation could participate in the regulation of distal regulatory regions (Hon et al., 2014; Lu et al., 2014).

In mammals, two waves of epigenetic reprogramming featuring global DNA demethylation take place in preimplantation embryos and primordial germ cells (PGCs). This genome-wide DNA demethylation involves inhibition of the $5 \mathrm{mC}$-maintenance DNA methyltransferase 1 (Dnmt1)/Ubiquitin-Like with PHD and Ring Finger Domains 1 (Uhrf1) enzyme complex and 'de novo' DNA methyltransferases 3a/b (Dnmt3a/b), followed by dilution of $5 \mathrm{mC}$ during DNA replication; a process also known as passive demethylation. Active, enzyme-mediated 'methyl-group' removal mechanism(s), in which $5 \mathrm{mC}$ is oxidized sequentially via Tet proteins into 5hydroxymethylcytosine $(5 \mathrm{hmC}), 5$-formylcytosine $(5 \mathrm{fC})$ and 5-carboxylcytosine $(5 \mathrm{caC})$, are also critical for epigenetic reprogramming.

\section{Global Demethylation in Preimplantation Embryo}

In mice, soon after fertilization, male and female pronuclei show differential demethylation kinetics (Mayer et al., 2000; Oswald et al., 2000). These observations have led to a model for DNA demethylation in which the male pronucleus undergoes active demethylation mediated by Tet3 (Iqbal et al., 2011). 5hmC and other oxidative products generated by TET proteins are removed via the base excision repair (BER) pathway as well as replication-dependent dilution ( $\mathrm{Gu}$ et al., 2011; Inoue and Zhang, 2011; Iqbal et al., 2011). In contrast slower demethylation kinetics are observed in the maternal pronucleus where histone H3Lys9-dimethylation marked chromatin (H3K9me2) has a tighter association with protein Stella/DPPA3 compared to the paternal pronucleus. This chromatin state has been suggested to protect the maternal pronucleus from active, Tet3-mediated demethylation (Nakamura et al., 2007, 2012; Messerschmidt, 2012). The finding that Tet3 predominantly localizes on paternal pronuclei further supports this model (Gu et al., 2011; Nakamura et al., 2012). Bisulfite sequencing and mass spectrometry have also shown pronounced demethylation in the zygote with different demethylation kinetics between paternal and maternal pronuclei (Guo F. et al., 2014; Okamoto et al., 2016). However, investigations at single-base-resolution show that Tet-mediated demethylation is operational in the maternal genome, albeit with slower kinetics compared to the paternal genome (Guo F. et al., 2014; Guo H. et al., 2014; Tsukada et al., 2015; Zhu et al., 2017).

While global demethylation persists until the late blastocyst stage (Okamoto et al., 2016), Tet3 expression rapidly diminishes at the 2-cell stage (maternal-zygotic transition) and is replaced by Tet1/2 around the morula stage ( $\mathrm{Gu}$ et al., 2011; Iqbal 
et al., 2011; Cao et al., 2014; Lee K. et al., 2014; Gao et al., 2017). Genome-wide methylation is restored in late blastocysts and continues during germ layer establishment (Inoue and Zhang, 2011; Guenatri et al., 2013). During this developmental stage, Dnmt3a/b exhibit distinct sequence preferences and target diverse genomic regions (Okano et al., 1999; Watanabe et al., 2002; Chen et al., 2004; Borgel et al., 2010; Velasco et al., 2010; Auclair et al., 2014; Liao et al., 2015), while Dnmt3l acts as cofactor (Ooi et al., 2007; Jurkowska et al., 2011). Overall, remodeling of the embryonic methylome has been suggested to be a double-check security system, in which the global demethylation contributes to the establishment of totipotency and prevents any potentially deleterious epigenetic inheritance, while the re-establishment of methylation is crucial for exit of totipotency/pluripotency and for efficient spatiotemporal control of genome activity and lineage decision (Guenatri et al., 2013; Lee H. J. et al., 2014).

A recent study suggested that in the mouse paternal genome Tet3 may function as an antagonist to de novo methylation activity in later zygotic stages, but is not necessarily required for demethylation before pronuclear stage 3 (PN3), as Tet3-independent $5 \mathrm{mC}$ erasure occurs before $5 \mathrm{hmC}$ is generated (Amouroux et al., 2016). Although Tet3-mediated active demethylation has been linked with paternal genome activation and activities of pluripotent genes such as Oct4 and Nanog (Ito et al., 2010; Guo F. et al., 2014), deletion of maternal Tet3 (Gu et al., 2011) does not seem to affect preimplantation development. This suggests that Tet3 functions may be compensated by the other two Tet enzymes, or defects in DNA active demethylation can be tolerated during preimplantation development. Heterozygous Tet3-KO mice show neonatal sub-lethality, suggesting that Tet3 disruption at early embryonic stages may affect later development (Gu et al., 2011; Inoue et al., 2015; Tsukada et al., 2015). It is possible that passive demethylation on the paternal genome is sufficient for preimplantation development. That is, partial impairment of symmetric maintenance DNA methylation at CpG dyads, rather than active demethylation, is thought to be the main driver of DNA demethylation of both paternal and maternal genome at the zygote stage and also in PGCs (Guo H. et al., 2014; Arand et al., 2015).

DNA methylation dynamics have also been studied in species other than mouse. Although the demethylation profiles in human and mice are generally similar (Smith et al., 2014), differences have been observed between the 2-cell to morula stages, such as an increase of methylation level at pronuclear stage and 4- to 8-cell stages in human embryo (Guo H. et al., 2014; Zhu et al., 2018). In humans rapid demethylation and hydroxymethylation are also observed in both male and female pronuclei, suggesting TET-mediated active demethylation on both the paternal and maternal genome (Guo H. et al., 2014). Similar to mouse (Salvaing et al., 2012; Li et al., 2016), 5mC and $5 \mathrm{hmC}$ co-exist in both pronuclei of human zygotes and in oocytes in a non-reciprocal pattern (Petrussa et al., 2016), which is consistent with the detection of de novo methylation at PN3 (Amouroux et al., 2016). In Rhesus monkey, a methylation peak was also reported at 8-cell stage, and de novo methylation was observed at some paternal and maternal $\mathrm{CpG}$ sites at 2-cell stage and onwards. Single-cell DNA methylome data of preimplantation human embryo further indicates de novo methylation is enriched for major families of repetitive elements, especially evolutionarily younger subfamilies, such as ALU and LINE1 retroelements (Zhu et al., 2018). These data indicate that, unlike the generally unidirectional demethylation suggested before, de novo methylation could be concurrent with and even 'outpace' DNA demethylation in preimplantation stages (Gao et al., 2017). It will be interesting to elucidate the mechanisms that support these transient waves of DNA methylation and their importance for normal development.

DNA methylation and hydroxymethylation profiling in early embryos of domestic animals, including bovine (Dobbs et al., 2013), porcine (Cao et al., 2014; Lee K. et al., 2014), ovine (Jafarpour et al., 2017; Masala et al., 2017), and equine (Heras et al., 2017), have mainly been reported via immunochemistry, separating $5 \mathrm{mC}$ and $5 \mathrm{hmC}$ at limited resolution. Although active demethylation is not observed in the maternal pronucleus, it has been reported in the paternal pronucleus of pig (Cao et al., 2014; Lee K. et al., 2014). Both paternal and maternal pronuclei in bovine show $5 \mathrm{hmC}$ signal, despite a much less pronounced $5 \mathrm{hmC}$ level detected in the maternal pronucleus (Wossidlo et al., 2011; Bakhtari and Ross, 2014). Controversial data have been reported for ovine embryos (Jafarpour et al., 2017; Masala et al., 2017). Jafarpour et al. reported a similar activedemethylation pattern between male and female pronucleus, i.e. strong $5 \mathrm{hmC}$ signal in both male and female pronucleus, whereas Masala et al. found $5 \mathrm{hmC}$ signal restricted to the paternal pronucleus (Jafarpour et al., 2017; Masala et al., 2017). In horse embryos produced by intracytoplasmic sperm injection (ICSI), both paternal and maternal pronuclei display strong $5 \mathrm{hmC}$ signals from PN1 to PN4, yet $5 \mathrm{mC}$ levels in both pronuclei are largely unchanged throughout pronuclear development (Heras et al., 2017). Furthermore, these studies reported species-specific TET expression in in vitro fertilized (IVF) and in vivo embryos, as well as aberrant demethylation in somatic cell nuclear transfer (SCNT) embryos (Cao et al., 2014; Zhang S. et al., 2016). The significant differences in staining between species suggest that additional methods that reduce the potential artifacts of immunostaining are essential to bring clarity on the conserved features of DNA demethylation in domestic animal embryos. A recent study used whole-genome, single-base DNA methylation profiling of individual porcine blastocysts, generated in vivo or by different IVF processes, and showed abnormally higher methylation levels and lower expression of Dnmt1, Uhrf1, and Dnmt3b in conventional IVF blastocysts compared to in vivo produced embryos (Canovas et al., 2017). These findings warrant further investigation into global demethylation of early embryos of different species and embryos generated by different assisted reproductive techniques.

\section{Erasure-Resistant Loci and Epigenetic Inheritance}

During global DNA demethylation in preimplantation embryos, methylation at loci with parental-specific imprints, 
retrotransposons as well as a portion of differentially methylated CGIs in oocyte-specific and sperm-specific methylated regions are at least partially maintained (Kobayashi et al., 2012; Smith et al., 2012, 2014; Monk, 2015). These methylated regions may be affected by parental life experience as well as in utero environment, which could be potential carriers of parental and early life epigenetic information and contribute to epigenetic inheritance. Recent studies show that the sperm methylome can be affected in one or multiple generations by diet (Holland et al., 2016), obesity (Donkin et al., 2016), drug addiction (Feng et al., 2015), stress/traumatic exposure (Franklin et al., 2010; Dias and Ressler, 2014; Gapp et al., 2014b), and toxins in the environment (Skinner et al., 2013; Nilsson and Skinner, 2015). Few studies report altered epigenetic signatures through the female germline, as it is difficult to separate them from the effects of in utero variations, including maternal hyperglycemia and gestational diabetes (Vrachnis et al., 2012).

Several factors have been shown to contribute to methylation maintenance at specific loci. Dnmt1 and Dnmt1o, the oocytespecific form of Dnmt1, contribute to DNA methylation maintenance at imprinted regions (Howell et al., 2001; Ratnam et al., 2002; Hirasawa et al., 2008). Interestingly, similar methylation-protective function of Dnmt1 has been observed in mouse PGCs in the absence of Uhrf1, which is suggested to regulate meiosis-related genes and ensure germline differentiation at the appropriate time (Hargan-Calvopina et al., 2016). Stella/PGC7 protects the maternal genome and ICRs (Imprinting Control Regions) from active demethylation via interaction with histone $\mathrm{H} 3 \mathrm{~K} 9 \mathrm{me} 2$. In the absence of Stella, loss of $5 \mathrm{mC}$ is observed in both pronuclei, accompanied by $5 \mathrm{hmC}$ accumulation in the maternal pronucleus (Wossidlo et al., 2011). Trim28/Zfp57 repressive complex which recruits Dnmt1/Uhrf1 as well as Dnmt3a/b is viewed as a non-canonical mechanism of maintaining DNA methylation at ICRs and retrotransposons in preimplantation embryos (Ideraabdullah et al., 2011; Strogantsev et al., 2015). Still, as most of these factors are found at ICRs and retrotransposons, it remains unclear whether similar mechanisms contribute to the maintenance of other methylated regions, especially methylation at genic regions. The Trim28/Zfp57 complex, as well as other Krüppel associated box (KRAB) family members with similar properties as Zfp57, could be potential mediators (Quenneville et al., 2011; Strogantsev et al., 2015). A recent study indicates that loss of maternal Trim28 leads to male-predominant embryo lethality before implantation due to demethylation and activation of Rbmylal gene, a testis-specific RNA-binding protein involved in alternative mRNA splicing (Sampath Kumar et al., 2017), which emphasizes the significance of methylation-protection mechanisms during early development. Interestingly, higher methylation level of the maternal genome compared to paternal genome is detected at a wide variety of genomic loci in both human embryonic and extra-embryonic lineages from 2-cell to early postimplantation stage, suggesting a potential role of preferential hypermethylation at maternal genome (Zhu et al., 2018). Overall, maintenance of DNA methylation at imprinted genes, retrotransposons and other unidentified genomic regions during epigenetic reprogramming appears to be required for normal development and viability. The identity and function, as well as the maintenance mechanism(s) of these methylated regions, are worth further exploration.

\section{Epigenetic Reprogramming in PGCs-Difference Between Rodent and Non-rodent Mammals}

The maintenance of methylation at imprinted regions is one of the key differences between global demethylation in embryos and in PGCs. Based on DNA methylation and expression profiles obtained from mouse PGCs (mPGCs), global demethylation in PGCs is mediated by two known mechanisms. The first mechanism is replication-dependent demethylation caused by repression of Dnmt3a/b and Uhrf1 expression, which leads to gradual loss of $5 \mathrm{mC}$ globally in pre-gonadal PGCs. The second mechanism, which operates mainly in mouse gonadal PGCs, is mediated via Tet $1 / 2$ which erase methylation at specific regions such as imprinted regions and germline-specific genes (Seisenberger et al., 2012; Wu and Zhang, 2014). This temporal and mechanistic separation of DNA demethylation in $\mathrm{mPGC}$ is suggested to safeguard the timing of germline differentiation (Hargan-Calvopina et al., 2016). The function of Tet1/2 on imprint erasure has been shown in several studies (Dawlaty et al., 2013; Hackett et al., 2013; Yamaguchi et al., 2013a,b). Tet1 may also be involved in regulation of meiosis (Yamaguchi et al., 2012), yet fertility of Tet1/2 single $\mathrm{KO}$ and double male KO mice is overtly normal (Table 1), which questions the functional redundancy and specificity of Tet proteins as well as the necessity of Tet1/2 during PGC demethylation and development. Alternatively, Tet $1 / 2$ and $5 \mathrm{mC}$ oxidation may be required to "kick-start" the demethylation process (Hahn et al., 2014).

The overall DNA demethylation dynamics are similar between mouse and human foetal germline. The methylome of gonadal PGCs reaches its lowest level at E13.5 in mouse and week $10(\mathrm{Wk} 10)$ in human, with most promoters and retrotransposons demethylated, yet global gene upregulation does not occur and genome integrity is protected, indicating the global uncoupling of DNA methylation and transcription during epigenetic reprogramming in PGCs. Still, in human PGCs (hPGCs) demethylated promoters of some meiosis-specific genes, such as KRAB-zinc finger proteins (ZFP) and genes of the P-element Induced Wimpy testis (PIWI) pathway, show correlation with increased expression, and are therefore named 'methylation-sensitive genes'. It is likely that in mammalian PGCs active demethylation at certain regions is required for regulation of germline-specific genes and germline differentiation (Tang et al., 2015; Hargan-Calvopina et al., 2016).

There are key features, at both transcriptional and epigenetic level, that differ between mouse and human PGC development. The temporal and mechanistic separation of DNA demethylation in mPGC may not be conserved in hPGCs. For example, the timing of imprinting erasure is earlier in hPGCs, possibly starting during the migratory phase (before $\mathrm{Wk} 4$ ). This observation is further supported by the upregulation of TET1 and detection of 5hmC in Wk4 hPGCs (Guo et al., 2015; Tang et al., 
TABLE 1 | Key regulators for DNA modifications and their knockout effects.

\begin{tabular}{|c|c|}
\hline Key DNA modification writer and editors & Effects of mutants \\
\hline Dnmt1 KO & $\begin{array}{l}\text { Embryonic lethality (Liao et al., 2015) } \\
\text { Conditional KO in PGCs lead to precocious meiosis in female PGCs and prospermatogonia differentiation in male } \\
\text { PGCs (Hargan-Calvopina et al., 2016) } \\
\text { Upregulation of post-migratory germ cell-specific genes in the somatic cells of the postimplantation embryo } \\
\text { (Maatouk et al., 2006) }\end{array}$ \\
\hline Dnmt3a KO & Postnatal lethality (Liao et al., 2015) \\
\hline Dnmt3b KO & Embryonic lethality (Liao et al., 2015) \\
\hline Dnmt3/ KO & Defects in meiosis (Vlachogiannis et al., 2015) \\
\hline Tet1 $\mathrm{KO}$ & $\begin{array}{l}\text { Viable and fertile (Dawlaty et al., 2011) Defects in imprinting erasure, smaller body size and subfertility (Yamaguchi } \\
\text { et al., 2013b) Defects in meiosis (Yamaguchi et al., 2012) }\end{array}$ \\
\hline Tet2 KO & $\begin{array}{l}\text { Defects in hematopoietic cell homeostasis(Li et al., 2011) } \\
\text { Viable and fertile (Wang et al., 2013) }\end{array}$ \\
\hline Maternal Tet3 KO & Neonatal sublethality (Inoue et al., 2015; Tsukada et al., 2015) \\
\hline Tet3 KO & Neonatal lethality (Gu et al., 2011; Wang et al., 2013) \\
\hline Tet1/2 DKO & $\begin{array}{l}\text { Viable (Wang et al., 2013) } \\
\text { Reduction in fertility (Dawlaty et al., 2013) }\end{array}$ \\
\hline Tet TKO & $\begin{array}{l}\text { Impaired morphogenesis and patterning. No headfolds, heart, somites and gut tube formed by E8.5 (Dai et al., } \\
\text { 2016) }\end{array}$ \\
\hline Alkbh1 KO & $\begin{array}{l}\text { Spermatogenic defects which lead to skewed sex ratio, unilateral defects in eye development and embryonic or } \\
\text { postnatal lethality, ranging from E9.5 to P28 (Nordstrand et al., 2010) } \\
\text { Defect in placental trophoblast lineage development (Pan et al., 2008) } \\
\text { Increased 6mA level in Alkbh1-KO mESCs (Wu et al., 2016) }\end{array}$ \\
\hline Fat mass and obesity-associated protein (Fto) & $\begin{array}{l}\text { Adipocyte size is smaller in Fto-KO mice when compared to WT mice after fed HFD (Church et al., 2009; Fischer } \\
\text { et al., 2009; Ronkainen et al., 2015) } \\
\text { KD and overexpression of FTO in two human cell lines (Jurkat-T, 293T) lead to increased and decreased 6mA } \\
\text { contents respectively (Huang et al., 2015) }\end{array}$ \\
\hline Thymine DNA glycosylase (TDG) KO & Embryonic lethality (Cortázar et al., 2011; Cortellino et al., 2011) \\
\hline
\end{tabular}

2015). In contrast, these changes are only observed in early gonadal mPGCs (after E9.5) (Chuva de Sousa Lopes et al., 2008; Guo et al., 2015; Tang et al., 2015; von Meyenn and Reik, 2015). Partial erasure of $5 \mathrm{mC}$ coupled with increased level of $5 \mathrm{hmC}$ at $\mathrm{H} 19$ and GNAS ICRs are also reported in day 4 (d4) and d5 human PGC-like cells (hPGCLCs) produced in vitro, which represent pre migratory PGCs (Tang et al., 2015). In contrast, DNA demethylation at $H 19$ promoter region is only detected after Wk9 in hPGCs (Eguizabal et al., 2016), suggesting that there is significant asynchrony in imprinted gene demethylation in human. Inaccessibility of human embryos at earlier stages prohibits investigations of the in vivo demethylation dynamics before week 4, i.e., during hPGC specification and early migration. Thus, developing a model that shares developmental mechanisms with human can be very informative for improving human PGC in vitro differentiation systems and for better understanding human PGC development. Our laboratory has developed the pig model, which closely resembles human development during the first three weeks of life. We showed that PGC develop in a similar fashion to what is known in human, and contrasts the process described in mice (Kobayashi et al., 2017).

We showed that global reduction of $5 \mathrm{mC}$ and $\mathrm{H} 3 \mathrm{~K} 9 \mathrm{me} 2$, as well as repression of the epigenetic modifiers UHRF1 and
EHMT2/G9a, in newly specified (E14) pre- and early migratory (E16) pig PGCs (Kobayashi et al., 2017). This finding indicates an earlier initiation of epigenetic reprogramming compared to mouse PGCs, but consistent with the timing in hPGCLCs (Kobayashi et al., 2017). Interestingly, along with the reduction of $5 \mathrm{mC}$, TET1 and $5 \mathrm{hmC}$ levels are significantly enriched in pre- and early migratory pig PGCs, consistent with largely erased imprinting in Wk4 hPGCs and expression changes of DNMT3a/b, UHRF1, and TET2 in early hPGCLCs (Kobayashi et al., 2017). In agreement with these findings, we showed that demethylation of the imprinted IGF2R in male pig PGCs initiates before pig PGCs reach the gonads (Hyldig et al., 2011).

Furthermore, nascent PGC cease to proliferate, suggesting that DNA demethylation is an active process dependent on recruitment of specific factors, such as Tet enzymes in pig PGCs (Kobayashi et al., 2017). These findings show a temporal and mechanistic difference of epigenetic reprogramming between rodents and non-rodent PGCs (Kobayashi et al., 2017). Consistent with these observations in the pig, $5 \mathrm{mC}$ and $\mathrm{H} 3 \mathrm{~K} 9 \mathrm{me} 2$ is also significantly lower in Cynomolgus monkey PGCs from as early as $\sim$ E17 and E20, respectively (Sasaki et al., 2016), further indicating a difference between PGC development in rodents and non-rodent mammals. Given the similarities 
between human and porcine embryos at a morphological, transcriptional and epigenetic level, as well as the accessibility of porcine embryos, the pig is a suitable surrogate model for investigating epigenetic reprogramming in human early PGCs and early embryos when combined with in vitro models for human embryonic development.

Although the methylated regions maintained during the reprogramming wave in preimplantation embryos are potential carriers of parental 'epimutations', they also need to 'escape' the global demethylation in PGCs to be able to contribute to transgenerational epigenetic inheritance. The idea of transgenerational inheritance of epigenetic states in mammal was first proposed about 30 years ago (Holliday, 1987; Laird, 1987). Although there is no definitive proof to show that DNA methylation marks can be maintained in germline and inherited across multiple generations in mammals, recent evidence suggests that DNA methylation at some genomic loci can escape both waves of epigenetic reprogramming (Seisenberger et al., 2012; Hackett et al., 2013; Guo et al., 2015; Tang et al., 2015). These regions are termed 'escapees', and a group of these escapees are repeat-poor, single copy genes which are associated with metabolic and neurological disorders (Tang et al., 2015).

Overall, redundant mechanisms have evolved to act in parallel for the efficient erasure of epigenetic marks in early embryos and PGCs, yet several mechanisms also exist to protect methylation at specific genomic regions, which could contribute to epigenetic inheritance. These demethylation and methylation-protection mechanisms may differ between rodent and non-rodent mammals given the different demethylation dynamics reported, suggesting recent and presumably ongoing evolutionary selection processes.

\section{SPECIFIC FEATURES OF $5 \mathrm{hmC}$}

\section{$5 \mathrm{hmC}$ as a Regulatory Marker}

$5 \mathrm{hmC}$ is mainly viewed as an intermediate product of active demethylation and is rapidly removed during replication (Inoue and Zhang, 2011) or further oxidized to $5 \mathrm{fC}$ and $5 \mathrm{caC}$. However, the non-reciprocal pattern between $5 \mathrm{mC}$ and $5 \mathrm{hmC}$ and the dynamics of hydroxymethylation observed during late oogenesis and early embryo development in multiple mammalian species suggest an additional biological role for 5hmC in early development (Masala et al., 2017). The enrichment of $5 \mathrm{hmC}$ and TET1/2 before and during pig PGC specification and early hPGCLC development also indicates the necessity of hydroxymethylation in non-rodent PGC development. The stability and abundance of $5 \mathrm{hmC}$ observed in mESCs further supports its biological significance (Bachman et al., 2014; Zhao et al., 2014). Still, the contribution of Tet proteins and $5 \mathrm{hmC}$ to pluripotency and differentiation is controversial. In mouse preimplantation embryos and $\mathrm{mESC}$ Tet functions are linked with pluripotency genes. For example, Tet3 deficiency in oocytes hinders DNA demethylation of the paternal Oct4 and Nanog genes in early embryos, and leads to delayed activation of a paternally derived Oct4 transgene (Gu et al., 2011; Guo F. et al., 2014). During somatic cell reprogramming of mouse induced-pluripotent cells (iPSCs),
Tet1 and Tet2 interact with Nanog and redundantly enhance Nanog-mediated reprogramming to pluripotency. However, recent data indicate that Tet1 and Tet2 have opposing effects during the establishment of naïve pluripotency, which is the 'ground' state of pluripotency in naïve epiblast in mice (Fidalgo et al., 2016). Tet1 partners with Zfp281 for establishing and maintaining primed pluripotency, and thereby also negatively regulates Tet 2 expression. Ectopic expression of Tet 2 alone in mESCs, but not Tet1 or Tet3, promotes reprogramming to naïve pluripotency, whereas knockdown (KD) of Tet2 leads to significantly reduced $5 \mathrm{hmC}$ at naïve pluripotency genes and compromised reprogramming to naïve state (Fidalgo et al., 2016). Other pluripotency genes, such as Oct4 (Piccolo et al., 2013) and Lin28 (Jiang and Baltimore, 2016; Tan and Yeo, 2016; Zeng et al., 2016), have also been related with Tet recruitment and its enzymatic activity.

It is largely unclear in which regions Tet-mediated active demethylation and $5 \mathrm{hmC}$ have transcriptional-regulating roles during pre-implantation embryo and PGC development. A recent study suggests that the enzymatic activity of Tet proteins, specifically of Tet3, is required for antagonizing Dnmt3a/b functions and regulating Lefty-Nodal signaling during gastrulation (Dai et al., 2016). Still, it remains unclear whether the requirement of Tet-mediated active demethylation is due to (1) protection of Lefty regions from passive demethylation and/or (2) a specific role of $5 \mathrm{hmC}$ at these loci. The transcriptional regulatory function of $5 \mathrm{hmC}$ may depend on different binding properties compared to $5 \mathrm{mC}$ or unmethylated $\mathrm{C}$, leading to a specific protein-binding profile at $5 \mathrm{hmC}$-enriched regions. For example, binding of $\mathrm{MeCP} 2, \mathrm{Mbd} 3$, and Uhrf1 to $5 \mathrm{hmC}$ was detected in vitro and in genomic DNA of mESCs and in the nervous system (Frauer et al., 2011; Yildirim et al., 2011; Mellén et al., 2012; Iurlaro et al., 2013; Chen et al., 2014). However, further studies suggest no binding preference for $5 \mathrm{hmC}$ and therefore these three proteins are unlikely to be $5 \mathrm{hmC}$ specific readers (Hashimoto et al., 2012; Mellén et al., 2012; Baubec et al., 2013; Spruijt et al., 2013; Cui and Irudayaraj, 2015; Gabel et al., 2015; Hainer et al., 2016). Additional uncharacterized proteins have been identified as $5 \mathrm{hmC}$ readers by Spruijt et al. (2013). For example, Uhrf2, a close relative of Uhrf1, shows strong preference for $5 \mathrm{hmC}$ and is considered a bona fide $5 \mathrm{hmC}$ reader (Spruijt et al., 2013). A further study reveals the structural basis of Uhrf2's preference for 5hmC (Zhou et al., 2014). KO of Uhrf2 in mice leads to reduction of $5 \mathrm{hmC}$ in the cortex and the hippocampus, along with abnormal expression of neuronalrelated genes and defects in spatial learning and memory (Chen R. et al., 2017). Another 5hmC-interacting protein identified is C3ORF37/Hmces/Srap1, a eukaryotic member of the SRAP superfamily (Aravind et al., 2013) that functions as an eraser of $5 \mathrm{hmC}$, in vitro and in mESCs. Srap1 KO causes sublethality in pre-implantation blastocysts, but the mutant mice are fertile, suggesting an unaffected PGC development (Kweon et al., 2017) and different reprogramming mechanisms between preimplantation embryo and PGCs.

Current genome-wide $5 \mathrm{hmC}$ detection techniques are not ideal for studies in early embryos or PGCs due to the amount of starting material required (Yu et al., 2012; Petterson et al., 
2014; Wu et al., 2014), as well as other technical limitations such as low genomic coverage (Sun et al., 2013; Han et al., 2016). Still, extensive research in mESCs and several other cell lines has shed some light on potential roles of $5 \mathrm{hmC}(\mathrm{Wu}$ and Zhang, 2011; Xu et al., 2011; Cimmino and Aifantis, 2017). The correlation between $5 \mathrm{hmC}$ and gene expression appears to be quite diverse and spatiotemporal-dependent. The genomic $5 \mathrm{hmC}$ pattern itself is also highly dynamic, which has been correlated with lineage-commitment gene expression and tissue-specific biological processes (Nestor et al., 2012; Lin et al., 2017; Ponnaluri et al., 2017). In general, $5 \mathrm{hmC}$ enrichment on gene bodies is linked with gene activation (Wu and Zhang, 2011; Guo et al., 2016; Lin et al., 2017; Ponnaluri et al., 2017). However, the effect of $5 \mathrm{hmC}$ enrichment on gene bodies has also been described as 'mildly inhibitory', as it correlates with modest gene upregulation (Neri et al., 2013). $5 \mathrm{hmC}$ on promoters and enhancers correlates with both active (Ficz et al., 2011; Stroud et al., 2011; Deplus et al., 2013) and repressed genes (Williams et al., 2011; Wu and Zhang, 2011; Choi et al., 2014; Kim et al., 2014; Zhang X. et al., 2016). Genomic 5hmC distribution is largely dependent on the activities of Tet proteins, which preferentially bind to promoters and gene bodies, but also enhancers with affinity that correlates with CpG density (Stroud et al., 2011; Williams et al., 2011; Branco et al., 2012). Tet1 and Tet3 contain a DNA binding CxxC domain which Tet2 lacks, yet the functional redundancy and specificity of Tets are still unresolved. Apart from potentially different contributions to pluripotency, in mouse embryo, Tet1, 2 , and 3 also show distinct expression profiles, suggesting that the requirement of Tet activities are highly context-dependent (Khoueiry et al., 2017). Also, Tet1, and Tet 2 show different localization in the genome, albeit with some overlap. Tet1 is suggested to be mainly responsible for $5 \mathrm{hmC}$ generation at promoters and some enhancers, while Tet 2 with $5 \mathrm{hmC}$ is present along gene bodies (Huang et al., 2014). Reduced 5hmC and increased $5 \mathrm{mC}$ are observed at enhancers in Tet $2^{-/-}$mESCs, which leads to reduced activities in a subset of enhancers and gene activation during mESC differentiation to neuronal fate, suggesting that Tet1 plays a role in the oxidation of some enhancers (Hon et al., 2014). The role of Tet proteins, especially around transcription start sites (TSSs), could be independent of their catalytic function (Williams et al., 2011), and more related to their interaction/recruitment with other proteins such as $\mathrm{O}$ Linked N-Acetylglucosamine (GlcNAc) Transferase (OGT) and Polycomb repressive complex 2 (PRC2) at CpG-rich regions ( $\mathrm{Wu}$ et al., 2011; Xu et al., 2011; Chen et al., 2013; Deplus et al., 2013; Neri et al., 2013; Vella et al., 2013). This may in part explain the active and repressive roles of $5 \mathrm{hmC}$. It is also possible that the genomic context of $5 \mathrm{hmC}$ contribute to the regulation of specific genes during development and differentiation by modulating chromatin accessibility (Ruzov et al., 2011). In foetal germ cells, genes with intermediate $5 \mathrm{hmC}$ levels of promoter regions are more likely to display higher chromatin accessibility and also have higher gene expression (Guo et al., 2016). Tet activity on insulators may also regulate gene expression by altering chromosomal architecture (Marina et al., 2016). 5hmC and Tet activities may affect other epigenetic markers or modifiers. For example, the correlation between $5 \mathrm{hmC}$ and bivalency, a poised epigenetic state defined by co-existence of active marker
H3Lys4-trimethylation (H3K4me3) and repressive H3Lys27trimethylation (H3K27me3), characteristic of pluripotent cells, has been reported in multiple studies (Pastor et al., 2011; Gao et al., 2013; Neri et al., 2013; Kong et al., 2016).

\section{The $5 \mathrm{mC} / 5 \mathrm{hmC}$ Asymmetry}

$5 \mathrm{mC}$ on DNA strands is considered symmetrical and is maintained by Dnmt1/Uhrf1 through replication, whereas Tetmediated active demethylation from $5 \mathrm{mC}$ is the only known origin of $5 \mathrm{hmC}$, with no known mechanism for maintenance through cell proliferation. Interestingly, asymmetric distribution and inheritance of $5 \mathrm{hmC}$ on complementary CpG sites between Watson and Crick strands (CpG dyads) is observed during mouse early embryogenesis (Guo H. et al., 2014; Mooijman et al., 2016) and in adult stem cells (Huh et al., 2013). This asymmetry is suggested to be mostly $5 \mathrm{mC} / 5 \mathrm{hmC}$, but unlikely to be $\mathrm{C} / 5 \mathrm{hmC}$ or $\mathrm{C} / 5 \mathrm{mC}$ at single CpG sites (Zhao et al., 2014). A high $5 \mathrm{mC} / 5 \mathrm{hmC}$ abundance at $\mathrm{CpG}$ dyads was also found in mESCs using a novel detection technique, suggesting potential biological functions for the $5 \mathrm{mC} / 5 \mathrm{hmC}$ modification status (Song et al., 2016). In vitro assays indicate that Uhrf1 and Dnmt3A can recognize hemihydroxymethylated substrates, whereas Dnmt1 cannot (Frauer et al., 2011). Further investigation of the activities of Tet proteins and Dnmt proteins in vivo may reveal if the $5 \mathrm{mC} / 5 \mathrm{hmC}$ asymmetry could be established by preferential oxidization, maintenance or de novo establishment of methylation on only one strand of $5 \mathrm{mC} / 5 \mathrm{mCpGs}$.

\section{FC AND 5CaC: INTERMEDIATES OF DEMETHYLATION OR REGULATORY MARKERS?}

$5 \mathrm{fC}$ and $5 \mathrm{caC}$ were considered as transient intermediate products of Tet-mediated active demethylation. During this process these modifications are removed by either passive dilution during replication, or are excised by thymine DNA glycosylase (Tdg) followed with base excision repair (BER) for replacement of an unmodified cytosine (He X.-J. et al., 2011; Maiti and Drohat, 2011). A recent study suggests that C3ORF37/Hmces/Srap1 functions as an eraser for $5 \mathrm{fC}$ and $5 \mathrm{caC}$ in mESCs (Kweon et al., 2017). The presence of $5 \mathrm{fC}(0.06-0.6 \%$ of $5 \mathrm{mC})$ and $5 \mathrm{caC}$ $(0.01 \%$ of $5 \mathrm{mC})$ in the mammalian genome is extremely low compared to $5 \mathrm{hmC}$ and $5 \mathrm{mC}$ (Ito et al., 2011; Pfaffeneder et al., 2011; Booth et al., 2014; Bachman et al., 2015). One potential explanation for this low occurrence is the preference of Tet for $5 \mathrm{mC}$ over $5 \mathrm{hmC} / 5 \mathrm{fC}$ ( $\mathrm{Hu}$ et al., 2015). Administration of stable isotope $\left[\right.$ methyl $\left.-{ }^{13} \mathrm{CD}_{3}\right] \mathrm{L}$-methionine tracked with liquid chromatography coupled to mass spectrometry/high resolution mass spectrometry (LC-MS/HRMS) further indicates that $5 \mathrm{fC}$ is a stable DNA modification in mESCs (Bachman et al., 2015). The stability of $5 \mathrm{fC}$ is also supported by another study indicating that the majority of $5 \mathrm{fC}$ at $\mathrm{CpG}$ sites is not removed via passive dilution during the gamete to 4-cell stage progression of the mouse embryo (Guo H. et al., 2014). However, neither 5fC nor $5 \mathrm{caC}$ were detected by mass spectrometry $8 \mathrm{~h}$ post-fertilization (Okamoto et al., 2016). Although $5 \mathrm{fC}$ and $5 \mathrm{caC}$ are considered relatively stable during mouse PGC development (E9.5 to E12.5), 
both epigenetic marks are not detected in human PGCs at comparable stages (Wk4-9) (Yamaguchi et al., 2013a; Tang et al., 2015).

\section{Distribution of $\mathbf{5 f C}$ and $\mathbf{5 c a C}$}

Reports indicate that $5 \mathrm{fC}$ and $5 \mathrm{caC}$ may stably exist at specific genomic regions, with distinct effects on gene expression. Several studies reported that $5 \mathrm{fC} / 5 \mathrm{caC}$ overlap with $\mathrm{H} 3 \mathrm{~K} 4 \mathrm{mel}$ marked regions which are associated with active or poised transcription (Shen et al., 2013; Song et al., 2013; Wu et al., 2014). In Tdg KO mESCs, promoters with silent or bivalent histone marks, as well as active enhancers and pluripotency TF-binding sites are enriched for ectopic $5 \mathrm{fC} / 5 \mathrm{caC}$ signals, indicating potential roles of $5 \mathrm{fC} / 5 \mathrm{caC}$ and targeted demethylation mediated via Tdg in mESCs (Shen et al., 2013). As ectopic $5 \mathrm{fC} / 5 \mathrm{caC}$ are also enriched at promoters of genes with low-to-medium expression levels, they are considered as 'mildly repressive' (Shen et al., 2013). Poised enhancers show enriched $5 \mathrm{fC}$ in $\mathrm{mESCs}$, and $\mathrm{p} 300$ based activation of enhancers coincides with an increase of $5 \mathrm{fC}$ in Tdg-KO mESCs (Song et al., 2013). Single-base mapping of $5 \mathrm{fC}$ and $5 \mathrm{caC}$ further confirm their enrichment at active enhancers and reveal differential genomic profiles for $5 \mathrm{fC}$ and $5 \mathrm{caC}$, with $5 \mathrm{fC}$ more frequently present in exons and promoter regions, and $5 \mathrm{caC}$ more frequently present in intronic regions. $5 \mathrm{fC}$ and $5 \mathrm{caC}$ are also detected with different sequence preference and binding sites of pluripotent genes. The gradient of $5 \mathrm{mC}$, $5 \mathrm{hmC}, 5 \mathrm{fC}$, and $5 \mathrm{caC}$ further indicates the correlation between Tet-mediate demethylation and the activation of regulatory elements in mESCs (Lu et al., 2015). Apart from the enrichment of $5 \mathrm{fC}$ on active enhancer regions, single-based $5 \mathrm{fC}$ profiles in multiple tissues also indicates clear tissue specificity of 5fC distribution (Iurlaro et al., 2016). More recently, 5fC was profiled in mouse early embryos in single cells at single base resolution, revealing stage-specific and parental-specific dynamics of 5fC. Interestingly, a critical set of developmental and metabolic related genes shows $5 \mathrm{fC}$ enrichment on promoters before gene upregulation (Zhu et al., 2017), which is also supported by the finding of transient $5 \mathrm{caC}$ accumulation at promoter regions preceding gene expression during lineage specification and differentiation (Lewis et al., 2017). These results highlight a fine balance between Tet oxidation and Tdg excision, suggesting potential roles for $5 \mathrm{fC} / 5 \mathrm{caC}$ and Tet/Tdg-mediated demethylation in embryonic development as well as tissuespecific processes. However, removal of $5 \mathrm{fC} / 5 \mathrm{caC}$ is largely independent of Tdg in both pre-implantation embryos (Guo F. et al., 2014; Guo H. et al., 2014; Zhu et al., 2017) and in mammalian PGCs (Yamaguchi et al., 2013a; Tang et al., 2015). This raises questions about the stability of $5 \mathrm{fC} / 5 \mathrm{caC}$ over replication-dependent passive dilution and suggests the existence of other removal mechanisms, such as the recently identified Srap nuclease (Kweon et al., 2017).

\section{Specific Functions and Protein Binding Partners for $5 \mathrm{fC}$ and $\mathbf{5 c a C}$}

Several studies have focused on the potential mechanisms underlying the correlations between $5 \mathrm{fC} / 5 \mathrm{caC}$ and the biological processes mentioned above (Spruijt et al., 2013; Song and Pfeifer,
2016). In vitro assays indicate that $5 \mathrm{fC}$ and $5 \mathrm{caC}$ lead to altered transcriptional properties, including increased backtracking, increased pausing, and reduced fidelity of mammalian RNA polymerase II (Pol II) in nucleotide incorporation (Kellinger et al., 2012). Structural and biochemical analysis show that specific hydrogen bonds are formed between the 5-carboxyl group of $5 \mathrm{caC}$ and the conserved epi-DNA recognition loop in Pol II. Comparison between Tdg-KO and wild-type mESCs shows a clear reduction of Pol II elongation in Tdg-KO cells, suggesting that $5 \mathrm{fC} / 5 \mathrm{caC}$ at gene bodies function as another layer of fine-tuning of Pol II transcription elongation in vivo (Wang et al., 2015). 5fC was reported to alter the DNA double helix structure which is likely to lead to helical unwinding in vitro (Raiber et al., 2015). However, compared to equivalent unmodified duplexes and sequence variants $5 \mathrm{fC}$ does not significantly affect the structure of the DNA double helix in a crystalline state (Hardwick et al., 2017). The alteration described by Raiber et al. (2015) is not unique to $5 \mathrm{fC}$ modified sequences, and therefore is unlikely to be the basis for $5 \mathrm{fC}$ recognition (Hardwick et al., 2017). Still, 5fC may trigger biological events by affecting the mechanical properties of DNA, for example, by increasing DNA flexibility (Ngo et al., 2016). Ngo et al. also show that $5 \mathrm{hmC}$ enhances flexibility, but is less effective compared to $5 \mathrm{fC}$, while $5 \mathrm{mC}$ reduces flexibility and $5 \mathrm{caC}$ is similar to unmodified cytosine in terms of structural qualities. DNA flexibility positively affects nucleosome stability, which may link $5 \mathrm{fC}$ with its regulatory role of gene expression at enhancer regions (Ngo et al., 2015, 2016). Protein binding affinity, which includes binding to histone octamers, is also affected by DNA flexibility (Peters and Maher, 2010). Screens for binding proteins indicates that there are more proteins with a strong preference for $5 \mathrm{fC}$ compared to $5 \mathrm{hmC}$, revealing the existence of potential 'readers' for $5 \mathrm{fC}$ which are involved in several biological processes including transcription regulation, chromatin regulation and DNA repair (Iurlaro et al., 2013).

Overall, although the stability of $5 \mathrm{fC}$ and $5 \mathrm{caC}$ requires validation, current data suggests that potential functions of $5 \mathrm{fC}$ and $5 \mathrm{caC}$ as well as their modifiers and readers are worth further investigations, especially in early embryos and PGCs with ongoing global DNA demethylation. Newly developed techniques which are cost-effective (Neri et al., 2016) and require small numbers of cells (Zhu et al., 2017) will be helpful in future studies to resolve these issues. Different biochemical characteristic of $5 \mathrm{hmC} / 5 \mathrm{fC} / 5 \mathrm{caC}$ and their biological roles, if validated, represent additional regulatory layers during active removal of $5 \mathrm{mC}$.

\section{$6 \mathrm{~mA}$}

$6 \mathrm{~mA}$, the most prevalent DNA modification in prokaryotes is used by bacteria to regulate the gene expression program related to DNA repair (Messer and Noyer-Weidner, 1988), virulence (Sarnacki et al., 2013) and cellular defense (Zaleski et al., 2005). Interestingly, $6 \mathrm{~mA}$ is considered a novel epigenetic mark in eukaryotes, as it has been reported only recently in several fungi (Mondo et al., 2017), ciliates (Tetrahymena thermophila) (Wang Y. et al., 2017), green algae (Chlamydomonas Reinhardtii) (Fu et al., 2015), nematodes (Caenorhabditis elegans) (Greer et al., 
2015), fruit fly (Drosophila melanogaster) (Luo et al., 2015; Zhang et al., 2015; O'Brown and Greer, 2016), zebrafish (Danio rerio) (Liu J. et al., 2016), african clawed frog (Xenopus laevis) (Koziol et al., 2016), and mammals (Koziol et al., 2016; Liu J. et al., 2016). Potential biological functions of $6 \mathrm{~mA}$ in eukaryotes include regulation of gene transcription (Fu et al., 2015; Wu et al., 2016; Mondo et al., 2017), cell cycle, transposon activities (Zhang et al., 2015; Liu J. et al., 2016), nucleosome positioning (Mondo et al., 2017), as well as ribosomal DNA preservation (Blackburn et al., 1983; Wang Y. et al., 2017) and crosstalk with histone modification ( $\mathrm{H} 3 \mathrm{~K} 4 \mathrm{me} 2)$, which contributes to transgenerational epigenetic inheritance (Greer et al., 2015). An in vitro study further reported a specific pausing effect of $6 \mathrm{~mA}$ on yeast RNA polymerase II (pol II) (Wang W. et al., 2017). However, the epigenome of C. elegans and D. melanogaster could be largely different to that of mammals, as they are nearly devoid of 5mC (Capuano et al., 2014; Greer et al., 2015; Zhang et al., 2015). Therefore, a potentially highly divergent distribution and functions of $6 \mathrm{~mA}$ occurring in these organisms may not be conserved in vertebrates. Indeed, $6 \mathrm{~mA}$ level in vertebrates is extremely low in various examined tissues, from $0.00009 \%$ $6 \mathrm{~mA} / \mathrm{A}$ detected in $X$. laevis tissues (Koziol et al., 2016) to the highest of $\sim 0.1-0.2 \% 6 \mathrm{~mA} / \mathrm{A}$ during early embryogenesis of zebrafish and pig (Liu J. et al., 2016). Also, the distribution of $6 \mathrm{~mA}$ seems highly species-specific. In X. laevis tissues and mouse tissues, the peaks of $6 \mathrm{~mA}$ are mainly found in non-genic regions, while only a small set of genes contains $6 \mathrm{~mA}$ (Koziol et al., 2016). $6 \mathrm{~mA}$ at genic regions is more frequent at introns and is nearly depleted from TSSs and exons, which is in contrast to the enrichment of $6 \mathrm{~mA}$ at or following TSS in Chlamydomonas and Drosophila genomes, or the even distribution of $6 \mathrm{~mA}$ in $C$. elegans genome. $6 \mathrm{~mA}$ is also enriched at intergenic over promoter regions in zebrafish oocytes and early embryos. However, in contrast to the above result in $X$. laevis and mouse tissue, $6 \mathrm{~mA}$ DNA immunoprecipitation sequencing (DIP-seq) revealed slight $6 \mathrm{~mA}$ enrichment after TSSs and at exons instead of introns in zebrafish (Liu J. et al., 2016). Most interestingly, in several eukaryotic species, a large portion of $6 \mathrm{~mA}$ detection peaks are within repetitive elements (REs), especially in simple repeat regions. Based on these findings, significant motif sequences have been identified in simple repeats and other REs (Liu J. et al., 2016; Wu et al., 2016).

Other distinct features of $6 \mathrm{~mA}$ have also been revealed, indicating that despite the overall low level of $6 \mathrm{~mA}$, this particular DNA modification could be very dynamic and functionally important in vertebrates. Half of the $6 \mathrm{~mA}$ sites in $X$. laevis tissues and mouse kidney seem to be tissue-specific, and GO term analysis indicates that genes modified by $6 \mathrm{~mA}$ are linked to different pathways, which could indicate either a tissue-specific role, or a species-specific role of $6 \mathrm{~mA}$ modification (Koziol et al., 2016). Abundance of $6 \mathrm{~mA}$ in oocytes and early embryo of zebrafish and pig (0.1-0.2\% 6mA/A) (Liu J. et al., 2016) suggests a specific role of $6 \mathrm{~mA}$ in early embryo development of $6 \mathrm{~mA}$. Interestingly, cancer cells and tissues display significantly decreased $6 \mathrm{~mA}$ levels when compared to normal cells and tissues, whereas cultured cells show hundred-fold elevated $6 \mathrm{~mA}$ levels compared to in vivo tissues, in both human and mouse
(Liang et al., 2016). These results suggest that $6 \mathrm{~mA}$ abundance could rapidly alter during changes of cell identity. $\mathrm{KO}$ of Alkbh1 in mESC, a possible $6 \mathrm{~mA}$ demethylase, revealed 550 downregulated genes which are enriched in development and lineage specification factors. In addition, imbalanced cell fate decisions during differentiation further suggest a critical role of $6 \mathrm{~mA}$ in early development. In Alkbh1 KO mESCs, $6 \mathrm{~mA}$ was found significantly enriched at the retained $5^{\prime}$ UTR and open reading frame 1 (ORF1) regions of full-length, evolutionarily young long interspersed nuclear element 1 (L1/LINE-1), along with elevated $5 \mathrm{mC}$ levels compared to wild-type mESCs. Further analysis indicated that active transposable elements-of the LINE1 class - could be repressed by $6 \mathrm{~mA}$, and thereby function as a silencing center for neighboring genes during differentiation $(\mathrm{Wu}$ et al., 2016), which contradicts previous suggestions that $6 \mathrm{~mA}$ may be an active mark for gene expression in lower eukaryotes (Fu et al., 2015; Mondo et al., 2017). Extra deposition of $6 \mathrm{~mA}$ on the X chromosome in Alkbh1 KO mESCs is also reported to have a long-lasting, repressive effect, which may partially explain the imbalanced cell fate decision observed during Alkbh1 KO mESCs differentiation. However, the observation of $A l k b h 1$ as a $6 \mathrm{~mA}$ demethylase was not supported by another study using Alkbh1 knockout mESCs and mouse embryonic fibroblasts (MEFs) as well as in vitro biochemical assays (Liu F. et al., 2016). Instead, Liu et al. suggest that Alkbh1 is a demethylase of m1A (N1methyladenosine on RNA), which affects the initiator methionyltransfer RNA (tRNA ${ }^{\mathrm{iMet}}$ ) level and translation initiation in mammalian cell lines. Moreover, the existence of $6 \mathrm{~mA}$ in mESCs and mouse tissues was recently questioned by a highly sensitive LC-MS method; in parallel, the same approach successfully detected $6 \mathrm{~mA}$ at a level of $0.7 \% 6 \mathrm{~mA} / \mathrm{A}$ in Chlamydomonas Reinhardtii genome (Schiffers et al., 2017). The authors suggested that the previous sequencing-derived data of $6 \mathrm{~mA}$ in mESCs might be caused by degraded bacterial DNA which provides the $6 \mathrm{~mA}$ nucleoside incorporated into mESC DNA (Schiffers et al., 2017). Therefore, further profiling and validation of DNA and RNA modification in wild type and Alkbh1 KO mammalian cell lines with different detection methods and contaminationeliminating strategies may help solve the controversy. In human cell lines, Fat mass and obesity-associated protein (FTO), which has previously been identified as a demethylase for N6methadenine on RNAs (m6A) both in vivo (Shen et al., 2015) and in vitro (Jia et al., 2011), is suggested as another $6 \mathrm{~mA}$ demethylase (Huang et al., 2015). Interestingly, the level of N6-methadenine on both DNA and RNA (Klungland and Dahl, 2014) seems to correlate with cellular fat mass and may be linked to obesity and type 2 diabetes (Huang et al., 2015).

Overall, the presence of $6 \mathrm{~mA}$ in eukaryotic genomes, especially lower eukaryotes, is evident, with divergent genomic distribution and functions observed in different eukaryotic species. Thus, it is worth further exploring novel modifications such as $6 \mathrm{~mA}$. If $6 \mathrm{~mA}$ truly has significant biological functions, the specificity of $6 \mathrm{~mA}$ establishment, removal and readout will be crucial for understanding its roles. Current data indicate a lack, or insufficient, consensus motifs for $6 \mathrm{~mA}$ establishment in vertebrate genomes based on in silico analysis (Koziol et al., 2016). It is possible that the 'modifiers' do not recognize specific 
sequences, but are recruited by different $6 \mathrm{~mA}$-binding proteins. Also, interesting features of $6 \mathrm{~mA}$ observed in lower eukaryotes, such as co-regulation with active histone mark H3K4me2 and involvement in transgenerational inheritance (Greer et al., 2015), have not been investigated in vertebrates.

It has been suggested that, in general, the levels of $6 \mathrm{~mA}$ and $5 \mathrm{mC}$ have an inverse relationship in organisms throughout the tree of life (O'Brown and Greer, 2016; Mondo et al., 2017). There seems to be an evolutionary shift from $6 \mathrm{~mA}$ to $5 \mathrm{mC}$ as the major epigenetic mark. It is worth mentioning that the Tet homolog is identified as $6 \mathrm{~mA}$ demethylase in Drosophila (Zhang et al., 2015), which supports such an evolutionary shift and also suggests the possibility of an inverse correlation between $5 \mathrm{mC}$ and $6 \mathrm{~mA}$ in eukaryotes (Breiling and Lyko, 2015). $6 \mathrm{~mA}$, unlike $5 \mathrm{mC}$, does not tend towards spontaneous mutations and therefore could be advantageous for genomic stability compared to $5 \mathrm{mC}$. Interestingly, the timing of $6 \mathrm{~mA}$ enrichment after fertilization (Liu J. et al., 2016) overlaps with the timing of global demethylation in zebrafish (Potok et al., 2013) and pig (Cao et al., 2014), in spite of the overall different dynamics between zebrafish and mammalian epigenetic reprogramming (O'Neill, 2013; Luo and He, 2017). It would be interesting to investigate if the enrichment of $6 \mathrm{~mA}$ is truly correlated with genome-wide demethylation and plays repressive roles complementary to $5 \mathrm{mC}$ on regions such as REs in preimplantation embryos and PGCs (Liu F. et al., 2016; Luo and He, 2017). Whether spatiotemporal changes of $6 \mathrm{~mA}$ levels occur under abnormal circumstances, such as the state of obesity and type 2 diabetes, is also worth exploring. However, the existence of $6 \mathrm{~mA}$ in animals and whether $6 \mathrm{~mA}$ is abundant or stable enough to elicit biological changes in vertebrate genomes still remains questionable.

\section{5mC AT NON-CpG SITES}

Although DNA methylation $(5 \mathrm{mC})$ is predominantly found on CpG sites in mammalian genomes, non-random distribution of non-CpG methylation is present in the mouse and human genome and has been studied for their biological relevance for over a decade (Pinney, 2014; He and Ecker, 2015). NonCpG methylation is present in most tissues (Schultz et al., 2015), but only prevalent in a few cell types and tissues such as ESCs (Ramsahoye et al., 2000; Lister et al., 2009; Ziller et al., 2011), brain (Guo J. U. et al., 2014; Kinde et al., 2015), and oocytes (Tomizawa et al., 2011; Shirane et al., 2013). Non-CpG methylation is also accumulated in mitotically arrested prospermatogonia (Kobayashi et al., 2013), but is largely lost after the resumption of mitosis (Ichiyanagi et al., 2013), which is consistent with the lack of maintenance mechanism for non-CpG methylation. Non-CpG methylation is almost exclusively established by $\mathrm{Dnmt} 3 \mathrm{a} / \mathrm{b}$ and requires the presence of Dnmt3L (Arand et al., 2012; Vlachogiannis et al., 2015). As Dnmtl generally does not contribute to non-CpG methylation, the distribution is asymmetrical between the two strands of individual DNA molecules. $5 \mathrm{hmC}$ on non-CpG sites is very rare, even in brain (Lister et al., 2013) and ESCs (Yu et al., 2012), suggesting that Tet-mediated demethylation is not required for removal of non-CpG methylation.
Non-CpG methylation has been suggested to be a by-product of Dnmt activity due to its strong link to neighboring CpG methylation (Ziller et al., 2011; Arand et al., 2012). However, motif analysis suggests that non-CpG methylation does have tissue-specific site preferences in the genome (Lister et al., 2009, 2013; Vlachogiannis et al., 2015). Apart from tissue-specific distribution, non-CpG methylation on promoters, enhancers and gene bodies also have been associated with transcriptional repression (Guo J. U. et al., 2014; Zhang et al., 2017) and protein binding activities (Barrès et al., 2009; Guo J. U. et al., 2014; Sperlazza et al., 2017). Aberrant non-CpG methylation patterns were shown in pluripotent cells (Lister et al., 2011; Ma et al., 2014), yet the correlation between non-CpG methylation and pluripotent states is largely unknown (Patil et al., 2014). Also, the prevalence of non-CpG methylation in oocytes is worth exploring, as maternally-derived methylation could have functions during early embryo development and therefore have the potential as carrier of epigenetic information (Branco et al., 2016).

\section{$5 \mathrm{hmU}$}

Apart from modifications on cytosine and adenine, oxidized thymine (T) nucleobases such as 5-hydroxymethyluracil (5hmU) are also found in mammalian cells. $5 \mathrm{hmU}$ was considered as a product of oxidative lesions (Bjelland et al., 1995) and mainly precursors of Base J ( $\beta$-D-Glucopyranosyloxymethyluracil) in eukaryotic kinetoplastid flagellates (van Luenen et al., 2012; Reynolds et al., 2014; Kawasaki et al., 2017). A recent study reports the presence of $5 \mathrm{hmU}$ in human, rat and porcine tissues at relatively stable levels (Gackowski et al., 2015). In mESCs, the majority of $5 \mathrm{hmU}$ is generated by Tet-catalyzed oxidation of thymine instead of reactive oxygen species (ROS)-induced oxidation. Compared to adult somatic tissue, $5 \mathrm{hmU}$ levels are elevated in mESCs and are found in amounts that are comparable to $5 \mathrm{caC}$. $5 \mathrm{hmU}$ levels peak between 8 and 16 hours after naïve $\mathrm{mESCs}$ begin differentiation towards post-implantation epiblast, suggesting $5 \mathrm{hmU}$ may be largely generated during epigenetic reprogramming (Pfaffeneder et al., 2014; Robertson et al., 2014). Although previous studies suggest that $5 \mathrm{hmU}$ can be produced via deamination of $5 \mathrm{hmC}$ by the Aid (activationinduced cytidine deaminase) / Apobec (apolipoprotein B mRNAediting catalytic polypeptides) family of enzymes (Cortellino et al., 2011; Guo et al., 2011), isotope tracing experiments in mESCs suggests that $5 \mathrm{hmC}$ is not a $5 \mathrm{hmU}$ precursor (Pfaffeneder et al., 2014). In vitro studies also suggest that $5 \mathrm{hmC}$ is an unlikely substrate for enzymes of the Aid/Apobec family (Nabel et al., 2012; Rangam et al., 2012; Budzko et al., 2017). A set of transcription factors and chromatin remodeling factors in nuclear extracts from mESCs have been identified as specific readers of $5 \mathrm{hmU}$ sites (Pfaffeneder et al., 2014). The Tetmediated elevated levels of $5 \mathrm{hmU}$ during mESC differentiation and the specific readers identified suggests that $5 \mathrm{hmU}$ may not simply be an oxidative lesion but have regulatory roles during early embryonic development. Further investigations of the $5 \mathrm{hmU}$ dynamics in mammalian model organisms are warranted (Olinski et al., 2016). 


\section{NOVEL MODIFICATION AND DISEASE}

As DNA methylation $(5 \mathrm{mC})$ is a well-recognized epigenetic regulator for gene expression, abnormality of $5 \mathrm{mC}$ profiles in various diseases (Robertson, 2005), including cancer (Esteller, 2008), aging-related disease (Gassen et al., 2017), cardiovascular diseases (Chistiakov et al., 2017), metabolic disorders (Wahl et al., 2017), reproductive disorders (Ho et al., 2017), and mental/neurological disorders (Nestler et al., 2016), have also been extensively studied and documented. Many of those diseases and their abnormal $5 \mathrm{mC}$ profiles may be attributable to early life experiences, suggesting the involvement of DNA methylation in the Developmental Origins of Health and Disease (DOHaD) paradigm (Leenen et al., 2016). Recent studies have also revealed potential roles of $5 \mathrm{hmC}$ in disease. Reduced $5 \mathrm{hmC}$ levels have been reported in a variety of cancers (Yang et al., 2013; Ficz and Gribben, 2014; Pfeifer et al., 2014; Rasmussen and Helin, 2016), which makes loss of $5 \mathrm{hmC}$ a potential hallmark of cancer (Chen Z. et al., 2017). Still, the biological consequence of the universal loss of $5 \mathrm{hmC}$ in tumorigenesis is not clear. Aberrant $5 \mathrm{hmC}$ pattern has also be observed in aging-related diseases (López et al., 2017), and age-related enrichment of $5 \mathrm{hmC}$ at specific loci has been observed in neural system (Szulwach et al., 2011; Chen et al., 2012). 5hmC has also been linked with neurological/mental disorders such as depression (Tseng et al., 2014; Gross et al., 2017), autism (Papale et al., 2015; Madrid et al., 2016), and Parkinson's disease (Stöger et al., 2017), as well as developmental disorders such as fragile $X$ syndrome (Brasa et al., 2016; Esanov et al., 2016). On the other hand, disease-related profiles of more recently discovered DNA modifications remain largely unknown. For example, decreased $6 \mathrm{~mA}$ level has been observed in cancers (Liang et al., 2016) and type 2 diabetes (Huang et al., 2015), suggesting that investigation of the role of $6 \mathrm{~mA}$ in those diseases is needed.

\section{FUTURE INVESTIGATION AND CHALLENGES}

All DNA modifications currently studied in mammalian genomes display their most dynamic profiles during epigenetic reprogramming in early development. Therefore, preimplantation embryos and PGCs, as well as their corresponding in vitro cell lines where epigenetic reprogramming also occurs, provide tractable systems for studying novel DNA modifications. Here we list a few aspects of novel DNA modifications that are worth exploring further:

\section{Genome-Wide Distribution of Novel Modification During Early Development and its Potential of Epigenetic Inheritance}

Genomic distribution of novel modifications may show specific spatiotemporal patterns during early development. Combined with other omics data, having a clear understanding of how these patterns are regulated may further our knowledge of the potential roles of these marks in development and inheritance.
Considering the low abundance of some of the DNA modifications, cross-validation by multiple strategies is required; this currently limits studies in rare cell types and tissues. For example, bisulfite sequencing is unable to distinguish between $5 \mathrm{mC}$ and $5 \mathrm{hmC}$, or unmethylated cytosines from $5 \mathrm{fC}$ and $5 \mathrm{caC}$, which may lead to misinterpretation of $5 \mathrm{mC}$ profiles and dynamics of active demethylation. Advanced techniques with improved sensitivity and specificity would allow genome-wide profiling of rare epigenetic markers in small numbers of specific cells, including PGCs, preimplantation embryos and sub-populations of cancer cells in vivo. This will bring new understanding about the biological role of those novel modifications. Also, comparing genome-wide distribution in different stages of the lifecycle will enable the distinction between genomic regions that maintain stable marks from those that are susceptible to environmental influences. Such high-resolution profiling of modifications will enhance our understanding of the potential role of different DNA modifications in epigenetic inheritance (Figure 1). Thirdgeneration sequencing, such as single-molecule real-time (SMRT) sequencing and Nanopore sequencing, is promising for DNA modification profiling, although the high error rate and poor quantification accuracy of third-generation sequencing need to be improved (Plongthongkum et al., 2014; Rhoads and Au, 2015; Rand et al., 2017; Simpson et al., 2017).

\section{Protein Binding Profiles of Novel Modifications and Epigenetic Manipulation}

With the identification and characterisation of potential DNA modifiers and binding proteins, mechanisms for the remodeling and maintenance of novel modifications can be further investigated and thereby provide clues about their regulatory role and biological significance during early development. Modulation of expression of DNA modificationbinding proteins are currently used for altering certain DNA modifications in vivo. However, these strategies cannot provide region-specific or subtle epigenetic changes which can be 'matched' with observed phenotype(s). With a comprehensive understanding of DNA modification-interacting proteins and CRISPR-related techniques, novel tools that allow epigenetic manipulation at a specific genomic region will provide direct evidence for correlations or causality between distinct epigenetic modifications and specific biological events, such as transgenerational epigenetic inheritance of disease risks (Magnani, 2014). Manipulation tools for several well-studied epigenetic modifications have already been applied (Liu X. S. et al., 2016; Thakore et al., 2016).

\section{"Rediscover" DNA Modifications and the Relationship With RNA Modifications}

The discovery of $6 \mathrm{~mA}$ in eukaryotic genomes makes it tempting to speculate that the existence of DNA modifications in eukaryotic genomes is much more diverse than previously thought. Some DNA modifications detected at levels comparable to $5 \mathrm{fC}$ and $5 \mathrm{caC}$ were considered as well-established DNA lesions 


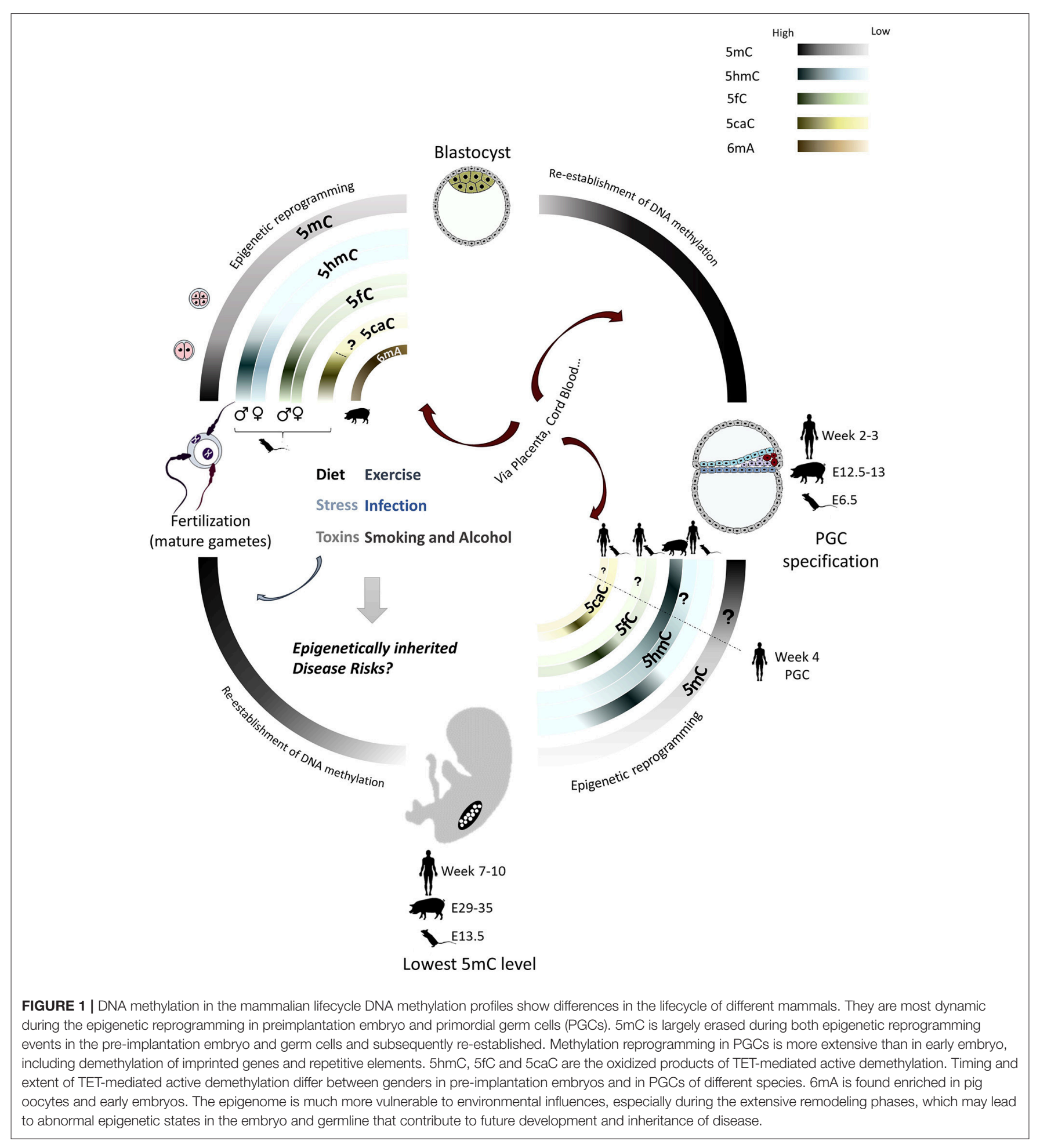

and therefore rarely investigated for biological significance. Recent studies suggest, other than causing genetic mutations, some of the rare DNA modifications may have biological functions via BER pathways, thereby representing a blur between DNA damage and epigenetic markers (Robertson et al., 2014; Ding et al., 2017; Fleming and Burrows, 2017).
On the other hand, modifications previously only in prokaryotic genomes or on RNA may be potential candidates for hitherto overlooked modifications in mammalian genomes. Some modifications and their binding proteins are 'shared' between DNA and RNA (Hudson and Ortlund, 2014). Similar to $6 \mathrm{~mA}$ and its suggested modifier FTO, $5 \mathrm{hmC}, 5 \mathrm{fC}$, and $5 \mathrm{caC}$ 
modification are also detected on RNA in mammals. Indeed, the latter mentioned RNA modifications have been suggested to be mediated by TET1 (Zhang H. Y. et al., 2016; BasantaSanchez et al., 2017). It would be of interest to identify the differences between DNA/RNA modifiers within a family that have significant preference towards DNA or RNA for further understanding of their functions and evolution. It is possible that during evolution these modifiers have shifted specificity from one type of nucleic acid to another, or lost their 'dual' specificity. Their ancient activities may not exist in vivo but might be observed in in vitro assays (Forterre and Grosjean, 2013).

RNA modifications may also be of great interest as they regulate RNA metabolism and gene expression at the translational level. RNA modifications and small non-coding RNAs are potential mediators of epigenetic inheritance in mammals. Recent reports indicate that malnutrition (Chen et al., 2016a; Sharma et al., 2016), stress/trauma (Gapp et al., 2014a; Rodgers et al., 2015) or exposure to toxins (Schuster et al., 2016) can lead to epigenetic inheritance mediated via small non-coding RNA in the male germline (Chen et al., 2016a; Watson, 2016). Elevated levels of 5-methylcytosine of RNA (m5C), which has been linked with increased stability of tRNA (Schaefer et al., 2010; Tuorto et al., 2012; Kiani et al., 2013), and N2-methylguanosine of RNA ( $\mathrm{m} 2 \mathrm{G}$ ) have both been observed on small RNAs in sperm from mice fed high fat diets (HFD); this apparently is linked with the transmission of metabolic disorders to offspring (Chen et al., 2016a). That is, RNA modifications could contribute to the transmission of metabolic disorder via sperm small RNAs (Chen et al., 2016,b).

\section{Interplay and Cooperation Within the Epigenome}

The relative instability of RNA makes it unlikely to mediate epigenetic inheritance on its own. The interplay and cooperation among different epigenetic markers, which are still largely unclear, are likely to be critical for modulating biological events such as epigenetic inheritance and early embryonic development as well as for maintaining genome stability and cell identity during epigenetic reprogramming. A recent study of vinclozolininduced transgenerational epigenetic inheritance indicates such

\section{REFERENCES}

Amouroux, R., Nashun, B., Shirane, K., Nakagawa, S., Hill, P. W., D'Souza, Z., et al. (2016). De novo DNA methylation drives $5 \mathrm{hmC}$ accumulation in mouse zygotes. Nat. Cell Biol. 18, 225-233. doi: 10.1038/nc b3296

Aran, D., Abu-Remaileh, M., Levy, R., Meron, N., Toperoff, G., Edrei, Y., et al. (2016). Embryonic stem cell (ES)-specific enhancers specify the expression potential of ES genes in cancer. PLoS Genet. 12:e1005840. doi: 10.1371/journal.pgen.1005840

Arand, J., Spieler, D., Karius, T., Branco, M. R., Meilinger, D., Meissner, A., et al. (2012). in vivo control of CpG and Non-CpG DNA methylation by DNA methyltransferases. PLoS Genet. 8:e1002750. doi: 10.1371/journal.pgen.1002750

Arand, J., Wossidlo, M., Lepikhov, K., Peat, J. R., Reik, W., and Walter, J. (2015). Selective impairment of methylation maintenance is the major cause of DNA association between differential methylated regions (DMRs) in F3 male germline, as early as E13, with sperm-borne small non-coding RNA (sncRNA) expression (Schuster et al., 2016). Co-existence of epigenetic modifications often indicate such cooperation within the epigenome and may reveal potential functions of novel DNA modifications. As mentioned above, apart from the correlation between $5 \mathrm{mC}$ and multiple histone modifications (Cedar and Bergman, 2009; Rose and Klose, 2014), $5 \mathrm{hmC}, 5 \mathrm{fC}, 5 \mathrm{caC}$, and $6 \mathrm{~mA}$ have also been reported to co-exist with certain histone modifications. New methods will be needed to detect multiple epigenetic modifications in the same context at individual loci within individual cells.

With more epigenetic modifications being discovered which can be highly dynamic, it will be necessary to establish databases curated for such information. Strides towards such goals are already in process. Recently, a manually curated database for epigenetic modifications during gametogenesis in seven mammals has been reported (Bai et al., 2017). Linkage between epigenetic modification databases with other databases such as interaction databases, pathway databases and disease-related databases would also be useful.

In summary, discovery and characterisation of novel DNA modifications are fascinating and fast-moving fields. DNA modifications often display extraordinarily dynamic patterns during early embryonic and germline development, yet the cause and consequence of these phenomena remain unclear. Therefore, exploring the dynamics of novel DNA modification during early development is a necessity for further understanding of DNA modifications in different biological contexts and a comprehensive epigenome map of mammalian genome.

\section{AUTHOR CONTRIBUTIONS}

QZ, RS, and RA conceived the ideas and wrote the review.

\section{ACKNOWLEDGMENTS}

QZ is supported by CSC and University of Nottingham. This work was supported by the Biotechnology and Biological Sciences Research Council [grant number BB/M001466/1].

methylation reprogramming in the early embryo. Epigenetics Chromatin 8:1. doi: 10.1186/1756-8935-8-1

Aravind, L., Anand, S., and Iyer, L. M. (2013). Novel autoproteolytic and DNAdamage sensing components in the bacterial SOS response and oxidized methylcytosine-induced eukaryotic DNA demethylation systems. Biol. Direct 8, 20-20. doi: 10.1186/1745-6150-8-20

Auclair, G., Guibert, S., Bender, A., and Weber, M. (2014). Ontogeny of CpG island methylation and specificity of DNMT3 methyltransferases during embryonic development in the mouse. Genome Biol. 15:545. doi: 10.1186/s13059-014-0545-5

Bachman, M., Uribe-Lewis, S., Yang, X., Burgess, H. E., Iurlaro, M., Reik, W., et al. (2015). 5-Formylcytosine can be a stable DNA modification in mammals. Nat. Chem. Biol. 11, 555-557. doi: 10.1038/nchembio.1848

Bachman, M., Uribe-Lewis, S., Yang, X., Williams, M., Murrell, A., and Balasubramanian, S. (2014). 5-Hydroxymethylcytosine is a predominantly stable DNA modification. Nat. Chem. 6, 1049-1055. doi: 10.1038/nchem.2064 
Bai, W., Yang, W., Wang, W., Wang, Y., Liu, C., Jiang, Q., et al. (2017). GED: a manually curated comprehensive resource for epigenetic modification of gametogenesis. Brief. Bioinformatics 18, 98-104. doi: 10.1093/bib/bbw007

Bakhtari, A., and Ross, P. J. (2014). DPPA3 prevents cytosine hydroxymethylation of the maternal pronucleus and is required for normal development in bovine embryos. Epigenetics 9, 1271-1279. doi: 10.4161/epi.32087

Barrès, R., Osler, M. E., Yan, J., Rune, A., Fritz, T., Caidahl, K., et al. (2009). Non-CpG methylation of the PGC-1 $\alpha$ promoter through DNMT3B controls mitochondrial density. Cell Metab. 10, 189-198. doi: 10.1016/j.cmet.2009.07.011

Basanta-Sanchez, M., Wang, R., Liu, Z., Ye, X., Li, M., Shi, X., et al. (2017). TET1mediated oxidation of 5 -formylcytosine $(5 \mathrm{fC})$ to 5 -carboxycytosine $(5 \mathrm{caC})$ in RNA. Chembiochem 18, 72-76. doi: 10.1002/cbic.201600328

Baubec, T., Ivánek, R., Lienert, F., and Schübeler, D. (2013). Methylationdependent and -independent genomic targeting principles of the MBD protein family. Cell 153, 480-492. doi: 10.1016/j.cell.2013.03.011

Bird, A. (2002). DNA methylation patterns and epigenetic memory. Genes Dev. 16, 6-21. doi: 10.1101/gad.947102

Bird, A. P., and Wolffe, A. P. (1999). Methylation-induced repression- belts, braces, and chromatin. Cell 99, 451-454. doi: 10.1016/S0092-8674(00)81532-9

Bjelland, S., Eide, L., Time, R. W., Stote, R., Eftedal, I., Volden, G., et al. (1995). Oxidation of thymine to 5-formyluracil in DNA: mechanisms of formation, structural implications, and base excision by human cell free extracts. Biochemistry 34, 14758-14764. doi: 10.1021/bi00045a017

Blackburn, E. H., Pan, W. C., and Johnson, C. C. (1983). Methylation of ribosomal RNA genes in the macronucleus of Tetrahymena thermophila. Nucleic Acids Res. 11, 5131-5145. doi: 10.1093/nar/11.15.5131

Booth, M. J., Marsico, G., Bachman, M., Beraldi, D., and Balasubramanian, S. (2014). Quantitative sequencing of 5-formylcytosine in DNA at single-base resolution. Nat. Chem. 6, 435-440. doi: 10.1038/nchem.1893

Borgel, J., Guibert, S., Li, Y., Chiba, H., Schübeler, D., Sasaki, H., et al. (2010). Targets and dynamics of promoter DNA methylation during early mouse development. Nat. Genet. 42, 1093-1100. doi: 10.1038/ng.708

Branco, M. R., Ficz, G., and Reik, W. (2012). Uncovering the role of 5-hydroxymethylcytosine in the epigenome. Nat. Rev. Genet. 13, 7-13. doi: $10.1038 / \mathrm{nrg} 3080$

Branco, M. R., King, M., Perez-Garcia, V., Bogutz, A. B., Caley, M., Fineberg, E., et al. (2016). Maternal DNA methylation regulates early trophoblast development. Dev. Cell 36, 152-163. doi: 10.1016/j.devcel.2015.12.027

Brasa, S., Mueller, A., Jacquemont, S., Hahne, F., Rozenberg, I., Peters, T., et al. (2016). Reciprocal changes in DNA methylation and hydroxymethylation and a broad repressive epigenetic switch characterize FMR1 transcriptional silencing in fragile X syndrome. Clin. Epigenetics 8, 15. doi: 10.1186/s13148-016-0181-x

Breiling, A., and Lyko, F. (2015). Epigenetic regulatory functions of DNA modifications: 5-methylcytosine and beyond. Epigenetics Chromatin 8, 24. doi: 10.1186/s13072-015-0016-6

Budzko, L., Jackowiak, P., Kamel, K., Sarzynska, J., Bujnicki, J. M., and Figlerowicz, M. (2017). Mutations in human AID differentially affect its ability to deaminate cytidine and 5-methylcytidine in ssDNA substrates in vitro. Sci. Rep. 7:3873. doi: 10.1038/s41598-017-03936-x

Canovas, S., Ivanova, E., Romar, R., García-Martínez, S., Soriano-Úbeda, C., García-Vázquez, F. A., et al. (2017). DNA methylation and gene expression changes derived from assisted reproductive technologies can be decreased by reproductive fluids. Elife 6:e23670. doi: 10.7554/eLife.23670

Cao, Z., Zhou, N., Zhang, Y., Zhang, Y., Wu, R., Li, Y., et al. (2014). Dynamic reprogramming of 5-hydroxymethylcytosine during early porcine embryogenesis. Theriogenology 81, 496-508. doi: 10.1016/j.theriogenology.2013.10.025

Capuano, F., Mülleder, M., Kok, R., Blom, H. J., and Ralser, M. (2014). Cytosine DNA methylation is found in drosophila melanogaster but absent in saccharomyces cerevisiae, schizosaccharomyces pombe, and other yeast species. Anal. Chem. 86, 3697-3702. doi: 10.1021/ac500447w

Cedar, H., and Bergman, Y. (2009). Linking DNA methylation and histone modification: patterns and paradigms. Nat. Rev. Genet. 10, 295-304. doi: $10.1038 / \operatorname{nrg} 2540$

Chen, H., Dzitoyeva, S., and Manev, H. (2012). Effect of aging on 5hydroxymethylcytosine in the mouse hippocampus. Restor. Neurol. Neurosci. 30, 237-245. doi: 10.3233/RNN-2012-110223
Chen, K., Zhao, B. S., and He, C. (2016). Nucleic acid modifications in regulation of gene expression. Cell Chem. Biol. 23, 74-85. doi: 10.1016/j.chembiol.2015.11.007

Chen, Q., Chen, Y., Bian, C., Fujiki, R., and Yu, X. (2013). TET2 promotes histone O-GlcNAcylation during gene transcription. Nature 493, 561-564. doi: 10.1038/nature11742

Chen, Q., Yan, M., Cao, Z., Li, X., Zhang, Y., Shi, J., et al. (2016a). Sperm tsRNAs contribute to intergenerational inheritance of an acquired metabolic disorder. Science 351, 397-400. doi: 10.1126/science.aad7977

Chen, Q., Yan, W., and Duan, E. (2016b). Epigenetic inheritance of acquired traits through sperm RNAs and sperm RNA modifications. Nat. Rev. Genet. 17, 733-743. doi: 10.1038/nrg.2016.106

Chen, R., Zhang, Q., Duan, X., York, P., Chen, G. D., Yin, P., et al. (2017). The 5-Hydroxymethylcytosine $(5 \mathrm{hmC})$ reader UHRF2 Is required for normal levels of $5 \mathrm{hmC}$ in mouse adult brain and spatial learning and memory. J. Biol. Chem. 292, 4533-4543. doi: 10.1074/jbc.M116.754580

Chen, T., Tsujimoto, N., and Li, E. (2004). The PWWP Domain of Dnmt3a and Dnmt3b Is required for directing DNA methylation to the major satellite repeats at pericentric heterochromatin. Mol. Cell. Biol. 24, 9048-9058. doi: 10.1128/MCB.24.20.9048-9058.2004

Chen, Y., Damayanti, N. P., Irudayaraj, J., Dunn, K., and Zhou, F. C. (2014). Diversity of two forms of DNA methylation in the brain. Front. Genet. 5:46. doi: 10.3389/fgene.2014.00046

Chen, Z., Shi, X., Guo, L., Li, Y., Luo, M., and He, J. (2017). Decreased 5hydroxymethylcytosine levels correlate with cancer progression and poor survival: a systematic review and meta-analysis. Oncotarget 8, 1944-1952. doi: 10.18632/oncotarget.13719

Chistiakov, D. A., Orekhov, A. N., and Bobryshev, Y. V. (2017). Treatment of cardiovascular pathology with epigenetically active agents: Focus on natural and synthetic inhibitors of DNA methylation and histone deacetylation. Int. J. Cardiol. 227(Suppl. C), 66-82. doi: 10.1016/j.ijcard.2016.11.204

Choi, I., Kim, R., Lim, H. W., Kaestner, K. H., and Won, K. J. (2014). 5hydroxymethylcytosine represses the activity of enhancers in embryonic stem cells: a new epigenetic signature for gene regulation. BMC Genomics 15:670. doi: 10.1186/1471-2164-15-670

Church, C., Lee, S., Bagg, E. A., McTaggart, J. S., Deacon, R., Gerken, T., et al. (2009). A mouse model for the metabolic effects of the human fat mass and obesity associated FTO gene. PLoS Genet. 5:e1000599. doi: 10.1371/journal.pgen.1000599

Chuva de Sousa Lopes, S. M., Hayashi, K., Shovlin, T. C., Mifsud, W., Surani, M. A., and McLaren, A. (2008). X chromosome activity in mouse XX primordial germ cells. PLoS Genet. 4:e30. doi: 10.1371/journal.pgen.0040030

Cimmino, L., and Aifantis, I. (2017). Alternative roles for oxidized mCs and TETs. Curr. Opin. Genet. Dev. 42, 1-7. doi: 10.1016/j.gde.2016.11.003

Cortázar, D., Kunz, C., Selfridge, J., Lettieri, T., Saito, Y., MacDougall, E., et al. (2011). Embryonic lethal phenotype reveals a function of TDG in maintaining epigenetic stability. Nature 470, 419-423. doi: 10.1038/nature 09672

Cortellino, S., Xu, J., Sannai, M., Moore, R., Caretti, E., Cigliano, A., et al. (2011). Thymine DNA glycosylase is essential for active DNA demethylation by linked deamination-base excision repair. Cell 146, 67-79. doi: 10.1016/j.cell.2011.06.020

Cui, Y., and Irudayaraj, J. (2015). Dissecting the behavior and function of MBD3 in DNA methylation homeostasis by single-molecule spectroscopy and microscopy. Nucleic Acids Res. 43, 3046-3055. doi: 10.1093/nar/ gkv098

Dai, H. Q., Wang, B. A., Yang, L., Chen, J. J., Zhu, G. C., Sun, M. L., et al. (2016). TET-mediated DNA demethylation controls gastrulation by regulating Lefty-Nodal signalling. Nature 538, 528-532. doi: 10.1038/nature 20095

Dawlaty, M. M., Breiling, A., Le, T., Raddatz, G., Barrasa, M. I., Cheng, A. W., et al. (2013). Combined deficiency of Tet1 and Tet 2 causes epigenetic abnormalities but is compatible with postnatal development. Dev. Cell 24, 310-323. doi: 10.1016/j.devcel.2012.12.015

Dawlaty, M. M., Ganz, K., Powell, B. E., Hu, Y. C., Markoulaki, S., Cheng, A. W., et al. (2011). Tet1 is dispensable for maintaining pluripotency and its loss is compatible with embryonic and postnatal development. Cell Stem Cell 9, 166-175. doi: 10.1016/j.stem.2011.07.010 
Deplus, R., Delatte, B., Schwinn, M. K., Defrance, M., Méndez, J., Murphy, N., et al. (2013). TET2 and TET3 regulate GlcNAcylation and H3K4 methylation through OGT and SET1/COMPASS. EMBO J. 32, 645-655. doi: 10.1038/emboj.2012.357

Dias, B. G., and Ressler, K. J. (2014). Parental olfactory experience influences behavior and neural structure in subsequent generations. Nat. Neurosci. 17, 89-96. doi: 10.1038/nn.3594

Ding, Y., Fleming, A. M., and Burrows, C. J. (2017). Sequencing the mouse genome for the oxidatively modified base 8-Oxo-7,8-dihydroguanine by OG-Seq. J. Am. Chem. Soc. 139, 2569-2572. doi: 10.1021/jacs.6b12604

Dobbs, K. B., Rodriguez, M., Sudano, M. J., Ortega, M. S., and Hansen, P. J. (2013). Dynamics of DNA methylation during early development of the preimplantation bovine embryo. PLoS ONE 8:e66230. doi: 10.1371/journal.pone.0066230

Donkin, I., Versteyhe, S., Ingerslev, L. R., Qian, K., Mechta, M., Nordkap, L., et al. (2016). Obesity and bariatric surgery drive epigenetic variation of spermatozoa in humans. Cell Metab. 23, 369-378. doi: 10.1016/j.cmet.2015.11.004

Edwards, J. R., Yarychkivska, O., Boulard, M., and Bestor, T. H. (2017). DNA methylation and DNA methyltransferases. Epigenetics Chromatin 10:23. doi: 10.1186/s13072-017-0130-8

Eguizabal, C., Herrera, L., De Oñate, L., Montserrat, N., Hajkova, P., and Belmonte, J. C. I. (2016). Characterization of the epigenetic changes during human gonadal primordial germ cells reprogramming. Stem Cells 34, 2418-2428. doi: $10.1002 /$ stem. 2422

Esanov, R., Andrade, N. S., Bennison, S., Wahlestedt, C., and Zeier, Z. (2016). The FMR1 promoter is selectively hydroxymethylated in primary neurons of fragile X syndrome patients. Hum. Mol. Genet. 25, 4870-4880. doi: $10.1093 / \mathrm{hmg} / \mathrm{ddw} 311$

Esteller, M. (2008). Epigenetics in cancer. New Engl. J. Med. 358, 1148-1159. doi: 10.1056/NEJMra072067

Feng, J., Shao, N., Szulwach, K. E., Vialou, V., Huynh, J., Zhong, C., et al. (2015). Role of Tet1 and 5-hydroxymethylcytosine in cocaine action. Nat. Neurosci. 18, 536-544. doi: 10.1038/nn.3976

Ficz, G., Branco, M. R., Seisenberger, S., Santos, F., Krueger, F., Hore, T. A., et al. (2011). Dynamic regulation of 5-hydroxymethylcytosine in mouse ES cells and during differentiation. Nature 473, U398-U589. doi: 10.1038/nature10008

Ficz, G., and Gribben, J. G. (2014). Loss of 5-hydroxymethylcytosine in cancer: cause or consequence? Genomics 104, 352-357. doi: 10.1016/j.ygeno.2014.08.017

Fidalgo, M., Huang, X., Guallar, D., Sanchez-Priego, C., Valdes, V. J., Saunders, A., et al. (2016). Zfp281 coordinates opposing Functions of Tet1 and Tet2 in pluripotent states. Cell Stem Cell 19, 355-369. doi: 10.1016/j.stem.2016.05.025

Fischer, J., Koch, L., Emmerling, C., Vierkotten, J., Peters, T., Brüning, J. C., et al. (2009). Inactivation of the Fto gene protects from obesity. Nature 458, 894-898. doi: 10.1038 /nature 07848

Fleming, A. M., and Burrows, C. J. (2017). 8-Oxo-7,8-dihydroguanine, friend and foe: epigenetic-like regulator versus initiator of mutagenesis. DNA Repair 56, 75-83. doi: 10.1016/j.dnarep.2017.06.009

Forterre, P., and Grosjean, H. (2013). The Interplay Between RNA and DNA Modifications: Back to the RNA World. Madame Curie Bioscience Database [Internet]. Austin, TX: Landes Bioscience, 2000-2013.

Franklin, T. B., Russig, H., Weiss, I. C., Gräff, J., Linder, N., Michalon, A., et al. (2010). Epigenetic transmission of the impact of early stress across generations. Biol. Psychiatry 68, 408-415. doi: 10.1016/j.biopsych.2010.05.036

Frauer, C., Hoffmann, T., Bultmann, S., Casa, V., Cardoso, M. C., Antes, I., et al. (2011). Recognition of 5-Hydroxymethylcytosine by the Uhrf1 SRA Domain. PLoS ONE 6:e21306. doi: 10.1371/journal.pone.0021306

Fu, Y., Luo, G.-Z., Chen, K., Deng, X., Yu, M., Han, D., et al. (2015). $\mathrm{N}(6)$-Methyldeoxyadenosine marks active transcription start sites in chlamydomonas. Cell 161, 879-892. doi: 10.1016/j.cell.2015.04.010

Gabel, H. W., Kinde, B., Stroud, H., Gilbert, C. S., Harmin, D. A., Kastan, N. R., et al. (2015). Disruption of DNA-methylation-dependent long gene repression in Rett syndrome. Nature 522, 89-93. doi: 10.1038/nature14319

Gackowski, D., Zarakowska, E., Starczak, M., Modrzejewska, M., and Olinski, R. (2015). Tissue-specific DIFFERENCES in DNA modifications (5-Hydroxymethylcytosine, 5-Formylcytosine, 5-carboxylcytosine and 5Hydroxymethyluracil) and their interrelationships. PLoS ONE 10: e0144859. doi: 10.1371/journal.pone.0144859
Gao, F., Niu, Y., Sun, Y. E., Lu, H., Chen, Y., Li, S., et al. (2017). De novo DNA methylation during monkey pre-implantation embryogenesis. Cell Res. 27, 526-539. doi: $10.1038 / \mathrm{cr} .2017 .25$

Gao, F., Xia, Y., Wang, J., Luo, H., Gao, Z., Han, X., et al. (2013). Integrated detection of both $5-\mathrm{mC}$ and $5 \mathrm{hmC}$ by high-throughput tag sequencing technology highlights methylation reprogramming of bivalent genes during cellular differentiation. Epigenetics 8, 421-430. doi: 10.4161/epi.24280

Gapp, K., Jawaid, A., Sarkies, P., Bohacek, J., Pelczar, P., Prados, J., et al. (2014a). Implication of sperm RNAs in transgenerational inheritance of the effects of early trauma in mice. Nat. Neurosci. 17, 667-669. doi: 10.1038/nn.3695

Gapp, K., Soldado-Magraner, S., Alvarez-Sánchez, M., Bohacek, J., Vernaz, G., Shu, H., et al. (2014b). Early life stress in fathers improves behavioural flexibility in their offspring. Nat. Commun. 5:5466. doi: 10.1038/ncomms6466

Gassen, N. C., Chrousos, G. P., Binder, E. B., and Zannas, A. S. (2017) Life stress, glucocorticoid signaling, and the aging epigenome: Implications for aging-related diseases. Neurosci. Biobehav. Rev. 74(Pt B), 356-365. doi: $10.1016 /$ j.neubiorev.2016.06.003

Greer, E. L., Blanco, M. A., Gu, L., Sendinc, E., Liu, J., Aristizábal-Corrales, D., et al. (2015). DNA methylation on N(6)-adenine in C. elegans. Cell 161, 868-878. doi: 10.1016/j.cell.2015.04.005

Gross, J. A., Pacis, A., Chen, G. G., Drupals, M., Lutz, P. E., Barreiro, L. B., et al. (2017). Gene-body 5-hydroxymethylation is associated with gene expression changes in the prefrontal cortex of depressed individuals. Transl. Psychiatry 7:e1119. doi: 10.1038/tp.2017.93

Gu, T. P., Guo, F., Yang, H., Wu, H. P., Xu, G. F., Liu, W., et al. (2011). The role of Tet3 DNA dioxygenase in epigenetic reprogramming by oocytes. Nature 477, 606-610. doi: 10.1038/nature10443

Guenatri, M., Duffié, R., Iranzo, J., Fauque, P., and Bourc'his, D. (2013). Plasticity in Dnmt3L-dependent and -independent modes of de novo methylation in the developing mouse embryo. Development 140, 562-572. doi: $10.1242 / \operatorname{dev} .089268$

Guo, F., Li, X., Liang, D., Li, T., Zhu, P., Guo, H., et al. (2014). Active and passive demethylation of male and female pronuclear dna in the mammalian zygote. Cell Stem Cell 15, 447-459. doi: 10.1016/j.stem.2014.08.003

Guo, F., Yan, L., Guo, H., Li, L., Hu, B., Zhao, Y., et al. (2015). The transcriptome and DNA methylome landscapes of human primordial germ cells. Cell 161, 1437-1452. doi: 10.1016/j.cell.2015.05.015

Guo, H., Hu, B., Yan, L., Yong, J., Wu, Y., Gao, Y., et al. (2016). DNA methylation and chromatin accessibility profiling of mouse and human fetal germ cells. Cell Res. 27, 165-183. doi: 10.1038/cr.2016.128

Guo, H., Zhu, P., Yan, L., Li, R., Hu, B., Lian, Y., et al. (2014). The DNA methylation landscape of human early embryos. Nature 511, 606-610. doi: $10.1038 /$ nature 13544

Guo, J. U., Su, Y., Shin, J. H., Shin, J., Li, H., Xie, B., et al. (2014). Distribution, recognition and regulation of non-CpG methylation in the adult mammalian brain. Nat. Neurosci. 17, 215-222. doi: 10.1038/nn.3607

Guo, J. U., Su, Y., Zhong, C., Ming, G. L., and Song, H. (2011). Hydroxylation of 5-Methylcytosine by TET1 Promotes Active DNA Demethylation in the Adult Brain. Cell 145, 423-434. doi: 10.1016/j.cell.2011.03.022

Hackett, J. A., Sengupta, R., Zylicz, J. J., Murakami, K., Lee, C., Down, T. A., et al. (2013). Germline DNA demethylation dynamics and imprint erasure through 5-hydroxymethylcytosine. Science 339, 448-452. doi: 10.1126/science.1229277

Hahn, M. A., Szabó, P. E., and Pfeifer, G. P. (2014). 5-hydroxymethylcytosine: a stable or transient DNA modification? Genomics 104, 314-323. doi: 10.1016/j.ygeno.2014.08.015

Hainer, S. J., McCannell, K. N., Yu, J., Ee, L. S., Zhu, L. J., Rando, O. J., et al. (2016). DNA methylation directs genomic localization of Mbd2 and Mbd3 in embryonic stem cells. Elife 5:e21964. doi: 10.7554/eLife.21964

Han, D., Lu, X., Shih, A. H., Nie, J., You, Q., Xu, M. M., et al. (2016). A highly sensitive and robust method for genome-wide $5 \mathrm{hmC}$ profiling of rare cell populations. Mol. Cell 63, 711-719. doi: 10.1016/j.molcel.2016.06.028

Hardwick, J. S., Ptchelkine, D., El-Sagheer, A. H., Tear, I., Singleton, D., Phillips, S. E. V., et al. (2017). 5-Formylcytosine does not change the global structure of DNA. Nat. Struct. Mol. Biol. 24, 544. doi: 10.1038/nsmb.3411

Hargan-Calvopina, J., Taylor, S., Cook, H., Hu, Z., Lee, S. A., Yen, M. R., et al. (2016). Stage-specific demethylation in primordial germ cells safeguards against precocious differentiation. Dev. Cell 39, 75-86. doi: 10.1016/j.devcel.2016.07.019 
Hashimoto, H., Liu, Y., Upadhyay, A. K., Chang, Y., Howerton, S. B., Vertino, P. M., et al. (2012). Recognition and potential mechanisms for replication and erasure of cytosine hydroxymethylation. Nucleic Acids Res. 40, 4841-4849. doi: 10.1093/nar/gks155

He, X.-J., Chen, T., and Zhu, J.-K. (2011). Regulation and function of DNA methylation in plants and animals. Cell Res. 21, 442-465. doi: $10.1038 / \mathrm{cr} .2011 .23$

He, Y., and Ecker, J. R. (2015). Non-CG methylation in the human genome. Annu. Rev. Genomics Hum. Genet. 16, 55-77. doi: 10.1146/annurev-genom-090413-025437

He, Y. F., Li, B. Z., Li, Z., Liu, P., Wang, Y., Tang, Q., et al. (2011). Tet-mediated formation of 5-carboxylcytosine and its excision by TDG in mammalian DNA. Science 333, 1303-1307. doi: 10.1126/science.1210944

Heras, S., Smits, K., De Schauwer, C., and Van Soom, A. (2017). Dynamics of 5-methylcytosine and 5-hydroxymethylcytosine during pronuclear development in equine zygotes produced by ICSI. Epigenet. Chromatin 10, 13. doi: 10.1186/s13072-017-0120-x

Heyn, H., Vidal, E., Ferreira, H. J., Vizoso, M., Sayols, S., Gomez, A., et al. (2016). Epigenomic analysis detects aberrant super-enhancer DNA methylation in human cancer. Genome Biol. 17, 11. doi: 10.1186/s13059-016-0879-2

Hirasawa, R., Chiba, H., Kaneda, M., Tajima, S., Li, E., Jaenisch, R., et al. (2008). Maternal and zygotic Dnmtl are necessary and sufficient for the maintenance of DNA methylation imprints during preimplantation development. Genes Dev. 22, 1607-1616. doi: 10.1101/gad.1667008

Hnisz, D., Day, D. S., and Young, R. A. (2016). Insulated neighborhoods: structural and functional units of mammalian gene control. Cell 167, 1188-1200. doi: 10.1016/j.cell.2016.10.024

Ho, S. M., Cheong, A., Adgent, M. A., Veevers, J., Suen, A. A., Tam, N. N. C., et al. (2017). Environmental factors, epigenetics, and developmental origin of reproductive disorders. Reprod Toxicol. 68(Suppl. C), 85-104. doi: 10.1016/j.reprotox.2016.07.011

Holland, M. L., Lowe, R., Caton, P. W., Gemma, C., Carbajosa, G., Danson, A. F., et al. (2016). Early-life nutrition modulates the epigenetic state of specific rDNA genetic variants in mice. Science 353, 495-498. doi: 10.1126/science. aaf7040

Holliday, R. (1987). The inheritance of epigenetic defects. Science 238, 163-170.

Holliday, R., and Pugh, J. E. (1975). DNA modification mechanisms and gene activity during development. Science 187, 226-232.

Hon, G. C., Rajagopal, N., Shen, Y., McCleary, D. F., Yue, F., Dang, M. D., et al. (2013). Epigenetic memory at embryonic enhancers identified in DNA methylation maps from adult mouse tissues. Nat. Genet. 45, 1198-1206. doi: 10.1038/ng.2746

Hon, G. C., Song, C. X., Du, T., Jin, F., Selvaraj, S., Lee, A. Y., et al. (2014). $5 \mathrm{mC}$ Oxidation by Tet 2 modulates enhancer activity and timing of transcriptome reprogramming during differentiation. Mol. Cell 56, 286-297. doi: 10.1016/j.molcel.2014.08.026

Howell, C. Y., Bestor, T. H., Ding, F., Latham, K. E., Mertineit, C., Trasler, J. M., et al. (2001). Genomic imprinting disrupted by a maternal effect mutation in the Dnmt1 gene. Cell 104, 829-838. doi: 10.1016/S0092-8674(01) 00280-X

Hu, L., Lu, J., Cheng, J., Rao, Q., Li, Z., Hou, H., et al. (2015). Structural insight into substrate preference for TET- mediated oxidation. Nature 527, 118-122. doi: 10.1038/nature15713

Huang, W., Xiong, J., Yang, Y., Liu, S. M., Yuan, B. F., and Feng, Y. Q. (2015). Determination of DNA adenine methylation in genomes of mammals and plants by liquid chromatography/mass spectrometry. RSC Adv. 5, 64046-64054. doi: 10.1039/C5RA05307B

Huang, Y., Chavez, L., Chang, X., Wang, X., Pastor, W. A., Kang, J., et al. (2014). Distinct roles of the methylcytosine oxidases Tet1 and Tet2 in mouse embryonic stem cells. Proc. Natl. Acad. Sci. U.S.A. 111, 1361-1366. doi: $10.1073 /$ pnas. 1322921111

Hudson, W. H., and Ortlund, E. A. (2014). The structure, function and evolution of proteins that bind DNA and RNA. Nat. Rev. Mol. Cell Biol. 15, 749-760. doi: $10.1038 / \mathrm{nrm} 3884$

Huh, Y. H., Cohen, J., and Sherley, J. L. (2013). Higher 5-hydroxymethylcytosine identifies immortal DNA strand chromosomes in asymmetrically self-renewing distributed stem cells. Proc. Natl. Acad. Sci. U.S.A. 110, 16862-16867. doi: $10.1073 /$ pnas. 1310323110
Hyldig, S. M., Croxall, N., Contreras, D. A., Thomsen, P. D., and Alberio, R. (2011). Epigenetic reprogramming in the porcine germ line. BMC Dev. Biol. 11:11. doi: $10.1186 / 1471-213 \mathrm{X}-11-42$

Ichiyanagi, T., Ichiyanagi, K., Miyake, M., and Sasaki, H. (2013). Accumulation and loss of asymmetric non-CpG methylation during male germ-cell development. Nucleic Acids Res. 41, 738-745. doi: 10.1093/nar/gks1117

Ideraabdullah, F. Y., Abramowitz, L. K., Thorvaldsen, J. L., Krapp, C., Wen, S. C., Engel, N., et al. (2011). Novel cis-regulatory function in ICR-mediated imprinted repression of H19. Dev. Biol. 355, 349-357. doi: 10.1016/j.ydbio.2011.04.036

Inoue, A., Shen, L., Matoba, S., and Zhang, Y. (2015). Haploinsufficiency, but not defective paternal $5 \mathrm{mC}$ oxidation, accounts for the developmental defects of maternal Tet3 knockouts. Cell Rep. 10, 463-470. doi: 10.1016/j.celrep.2014.12.049

Inoue, A., and Zhang, Y. (2011). Replication-dependent loss of 5Hydroxymethylcytosine in mouse preimplantation embryos. Science 334, 194-194. doi: 10.1126/science. 1212483

Iqbal, K., Jin, S. G., Pfeifer, G. P., and Szabó, P. E. (2011). Reprogramming of the paternal genome upon fertilization involves genome-wide oxidation of 5-methylcytosine. Proc. Natl. Acad. Sci. U.S.A. 108, 3642-3647. doi: 10.1073/pnas. 1014033108

Ito, S., D’Alessio, A. C., Taranova, O. V., Hong, K., Sowers, L. C., and Zhang, Y. (2010). Role of Tet proteins in $5 \mathrm{mC}$ to $5 \mathrm{hmC}$ conversion, EScell self-renewal and inner cell mass specification. Nature 466, 1129-1133. doi: $10.1038 /$ nature09303

Ito, S., and Kuraoka, I. (2015). Epigenetic modifications in DNA could mimic oxidative DNA damage: A double-edged sword. DNA Repair (Amst). 32, 52-57. doi: 10.1016/j.dnarep.2015.04.013

Ito, S., Shen, L., Dai, Q., Wu, S. C., Collins, L. B., Swenberg, J. A., et al. (2011). Tet proteins can convert 5-methylcytosine to 5-formylcytosine and 5-carboxylcytosine. Science 333, 1300-1303. doi: 10.1126/science.1210597

Iurlaro, M., Ficz, G., Oxley, D., Raiber, E. A., Bachman, M., Booth, M. J., et al. (2013). A screen for hydroxymethylcytosine and formylcytosine binding proteins suggests functions in transcription and chromatin regulation. Genome Biol. 14, R119. doi: 10.1186/gb-2013-14-10-r119

Iurlaro, M., McInroy, G. R., Burgess, H. E., Dean, W., Raiber, E. A., Bachman, M., et al. (2016). in vivo genome-wide profiling reveals a tissue-specific role for 5-formylcytosine. Genome Biol. 17, 141. doi: 10.1186/s13059-016-1001-5

Iyer, L. M., Zhang, D., Maxwell Burroughs, A., and Aravind, L. (2013). Computational identification of novel biochemical systems involved in oxidation, glycosylation and other complex modifications of bases in DNA. Nucleic Acids Res. 41, 7635-7655. doi: 10.1093/nar/gkt573

Jafarpour, F., Hosseini, S. M., Ostadhosseini, S., Abbasi, H., Dalman, A., and Nasr-Esfahani, M. H. (2017). Comparative dynamics of 5-methylcytosine reprogramming and TET family expression during preimplantation mammalian development in mouse and sheep. Theriogenology 89, 86-96. doi: 10.1016/j.theriogenology.2016.10.010

Jia, G., Fu, Y., Zhao, X., Dai, Q., Zheng, G., Yang, Y., et al. (2011). N6Methyladenosine in nuclear RNA is a major substrate of the obesity-associated FTO. Nat. Chem. Biol. 7, 885-887. doi: 10.1038/nchembio.687

Jiang, S., and Baltimore, D. (2016). RNA-binding protein Lin28 in cancer and immunity. Cancer Lett. 375, 108-113. doi: 10.1016/j.canlet.2016.02.050

Jones, P. A. (2012). Functions of DNA methylation: islands, start sites, gene bodies and beyond. Nat. Rev. Genet. 13, 484-492. doi: 10.1038/nrg3230

Jurkowska, R. Z., Jurkowski, T. P., and Jeltsch, A. (2011). Structure and function of mammalian DNA methyltransferases. Chembiochem 12, 206-222. doi: 10.1002/cbic. 201000195

Kawasaki, F., Beraldi, D., Hardisty, R. E., McInroy, G. R., van Delft, P., and Balasubramanian, S. (2017). Genome-wide mapping of 5hydroxymethyluracil in the eukaryote parasite Leishmania. Genome Biol. 18, 23. doi: 10.1186/s13059-017-1150-1

Kellinger, M. W., Song, C. X., Chong, J., Lu, X. Y., He, C., and Wang, D. (2012). 5 formylcytosine and 5-carboxylcytosine reduce the rate and substrate specificity of RNA polymerase II transcription. Nat. Struct. Mol. Biol. 19, 831-833. doi: $10.1038 /$ nsmb.2346

Khoueiry, R., Sohni, A., Thienpont, B., Luo, X., Velde, J. V., Bartoccetti, M., et al. (2017). Lineage-specific functions of TET1 in the postimplantation mouse embryo. Nat. Genet. 49, 1061-1072. doi: 10.1038/ng.3868 
Kiani, J., Grandjean, V., Liebers, R., Tuorto, F., Ghanbarian, H., Lyko, F., et al. (2013). RNA-mediated epigenetic heredity requires the cytosine methyltransferase Dnmt2. PLoS Genet. 9:e1003498. doi: 10.1371/journal.pgen.1003498

Kim, M., Park, Y. K., Kang, T. W., Lee, S. H., Rhee, Y. H., Park, J. L., et al. (2014). Dynamic changes in DNA methylation and hydroxymethylation when hES cells undergo differentiation toward a neuronal lineage. Hum. Mol. Genet. 23, 657-667. doi: 10.1093/hmg/ddt453

Kinde, B., Gabel, H. W., Gilbert, C. S., Griffith, E. C., and Greenberg, M. E. (2015). Reading the unique DNA methylation landscape of the brain: Non-CpG methylation, hydroxymethylation, and MeCP2. Proc. Natl. Acad. Sci. U.S.A. 112, 6800-6806. doi: 10.1073/pnas.1411269112

Klungland, A., and Dahl, J. A. (2014). Dynamic RNA modifications in disease. Curr. Opin. Genet. Dev. 26, 47-52. doi: 10.1016/j.gde.2014.05.006

Kobayashi, H., Sakurai, T., Imai, M., Takahashi, N., Fukuda, A., Yayoi, O., et al. (2012). Contribution of intragenic DNA methylation in mouse gametic DNA methylomes to establish oocyte-specific heritable marks. PLoS Genet. 8:e1002440. doi: 10.1371/journal.pgen.1002440

Kobayashi, H., Sakurai, T., Miura, F., Imai, M., Mochiduki, K., Yanagisawa, E., et al. (2013). High-resolution DNA methylome analysis of primordial germ cells identifies gender-specific reprogramming in mice. Genome Res. 23, 616-627. doi: $10.1101 /$ gr.148023.112

Kobayashi, T., Zhang, H., Tang, W. W. C., Irie, N., Withey, S., Klisch, D., et al. (2017). Principles of early human development and germ cell program from conserved model systems. Nature 546, 416-420. doi: 10.1038/nature22812

Kong, L., Tan, L., Lv, R., Shi, Z., Xiong, L., Wu, F., et al. (2016). A primary role of TET proteins in establishment and maintenance of De Novo bivalency at CpG islands. Nucleic Acids Res. 44, 8682-8692. doi: 10.1093/nar/gkw529

Koziol, M. J., Bradshaw, C. R., Allen, G. E., Costa, A. S. H., Frezza, C., and Gurdon, J. B. (2016). Identification of methylated deoxyadenosines in vertebrates reveals diversity in DNA modifications. Nat. Struct. Mol. Biol. 23, 24-30. doi: $10.1038 / \mathrm{nsmb} .3145$

Kweon, S. M., Zhu, B., Chen, Y., Aravind, L., Xu, S. Y., and Feldman, D. E. (2017). Erasure of Tet-Oxidized 5-Methylcytosine by a SRAP Nuclease. Cell Rep. 21, 482-494. doi: 10.1016/j.celrep.2017.09.055

Laird, C. D. (1987). Proposed mechanism of inheritance and expression of the human fragile-X syndrome of mental retardation. Genetics 117, 587-599.

Law, J. A., and Jacobsen, S. E. (2010). Establishing, maintaining and modifying DNA methylation patterns in plants and animals. Nat. Rev. Genet. 11, 204-220. doi: $10.1038 / \operatorname{nrg} 2719$

Lee, H. J., Hore, T. A., and Reik, W. (2014). Reprogramming the methylome: erasing memory and creating diversity. Cell Stem Cell 14, 710-719. doi: 10.1016/j.stem.2014.05.008

Lee, K., Hamm, J., Whitworth, K., Spate, L., Park, K. W., Murphy, C. N., et al. (2014). Dynamics of TET family expression in porcine preimplantation embryos is related to zygotic genome activation and required for the maintenance of NANOG. Dev. Biol. 386, 86-95. doi: 10.1016/j.ydbio.2013.11.024

Leenen, F. A., Muller, C. P., and Turner, J. D. (2016). DNA methylation: conducting the orchestra from exposure to phenotype? Clin. Epigenetics 8, 92. doi: 10.1186/s13148-016-0256-8

Lewis, L. C., Lo, P. C., Foster, J. M., Dai, N., Corrêa, I. R., Durczak, P. M., et al. (2017). Dynamics of 5-carboxylcytosine during hepatic differentiation: potential general role for active demethylation by DNA repair in lineage specification. Epigenetics 12, 277-286. doi: 10.1080/15592294.2017.1292189

Li, Y., Seah, M. K. Y., and O’Neill, C. (2016). Mapping global changes in nuclear cytosine base modifications in the early mouse embryo. Reproduction 151, 83-95. doi: 10.1530/REP-15-0207

Li, Z., Cai, X., Cai, C. L., Wang, J., Zhang, W., Petersen, B. E., et al. (2011). Deletion of Tet 2 in mice leads to dysregulated hematopoietic stem cells and subsequent development of myeloid malignancies. Blood 118, 4509-4518. doi: 10.1182/blood-2010-12-325241

Liang, D., Wang, H., Song, W., Xiong, X., Zhang, X., Hu, Z., et al. (2016). The decreased N6-methyladenine DNA modification in cancer cells. Biochem. Biophys. Res. Commun. 480, 120-125. doi: 10.1016/j.bbrc.2016.09.136

Liao, J., Karnik, R., Gu, H., Ziller, M. J., Clement, K., Tsankov, A. M., et al. (2015). Targeted disruption of DNMT1, DNMT3A and DNMT3B in human embryonic stem cells. Nat. Genet. 47, 469-478. doi: 10.1038/ng.3258
Lin, I. H., Chen, Y. F., and Hsu, M. T. (2017). Correlated 5-Hydroxymethylcytosine $(5 \mathrm{hmC})$ and gene expression profiles underpin gene and organ-specific epigenetic regulation in adult mouse brain and liver. PLOS ONE 12:e0170779. doi: 10.1371/journal.pone.0170779

Lister, R., Mukamel, E. A., Nery, J. R., Urich, M., Puddifoot, C. A., Johnson, N. D., et al. (2013). Global epigenomic reconfiguration during mammalian brain development. Science 341, 1237905-1237905. doi: 10.1126/science.1237905

Lister, R., Pelizzola, M., Dowen, R. H., Hawkins, R. D., Hon, G., Tonti-Filippini, J., et al. (2009). Human DNA methylomes at base resolution show widespread epigenomic differences. Nature 462, 315-322. doi: 10.1038/nature08514

Lister, R., Pelizzola, M., Kida, Y. S., Hawkins, R. D., Nery, J. R., Hon, G., et al. (2011). Hotspots of aberrant epigenomic reprogramming in human induced pluripotent stem cells. Nature 471, 68-73. doi: 10.1038/nature09798

Liu, F., Clark, W., Luo, G., Wang, X., Fu, Y., Wei, J., et al. (2016). ALKBH1-mediated tRNA demethylation regulates translation. Cell 167, 816.e816-828.e816. doi: 10.1016/j.cell.2016.09.038

Liu, J., Zhu, Y., Luo, G. Z., Wang, X., Yue, Y., Wang, X., et al. (2016). Abundant DNA 6mA methylation during early embryogenesis of zebrafish and pig. Nat. Commun. 7:13052. doi: 10.1038/ncomms13052

Liu, X. S., Wu, H., Ji, X., Stelzer, Y., Wu, X., Czauderna, S., et al. (2016). Editing DNA methylation in the mammalian genome. Cell 167, 233.e217-247.e217. doi: 10.1016/j.cell.2016.08.056

López, V., Fernández, A. F., and Fraga, M. F. (2017). The role of 5hydroxymethylcytosine in development, aging and age-related diseases. Ageing Res. Rev. 37(Suppl. C), 28-38. doi: 10.1016/j.arr.2017.05.002

Lu, F., Liu, Y., Jiang, L., Yamaguchi, S., and Zhang, Y. (2014). Role of Tet proteins in enhancer activity and telomere elongation. Genes Dev. 28, 2103-2119. doi: $10.1101 / \operatorname{gad} .248005 .114$

Lu, X., Han, D., Zhao, B. S., Song, C. X., Zhang, L. S., Doré, L. C., et al (2015). Base-resolution maps of 5-formylcytosine and 5-carboxylcytosine reveal genome-wide DNA demethylation dynamics. Cell Res. 25, 386-389. doi: $10.1038 / \mathrm{cr} .2015 .5$

Luo, G.-Z., Blanco, M. A., Greer, E. L., He, C., and Shi, Y. (2015). DNA N6methyladenine: a new epigenetic mark in eukaryotes? Nat. Rev. Mol. Cell Biol. 16, 705-710. doi: 10.1038/nrm4076

Luo, G.-Z., and He, C. (2017). DNA N6-methyladenine in metazoans: functional epigenetic mark or bystander? Nat. Struct. Mol. Biol. 24, 503-506. doi: $10.1038 / \mathrm{nsmb} .3412$

Ma, H., Morey, R., O’Neil, R. C., He, Y., Daughtry, B., Schultz, M. D., et al. (2014). Abnormalities in human pluripotent cells due to reprogramming mechanisms. Nature 511, 177-183. doi: 10.1038/nature13551

Maatouk, D. M., Kellam, L. D., Mann, M. R. W., Lei, H., Li, E., Bartolomei, M. S., et al. (2006). DNA methylation is a primary mechanism for silencing postmigratory primordial germ cell genes in both germ cell and somatic cell lineages. Development 133, 3411-3418. doi: 10.1242/dev. 02500

Madrid, A., Papale, L. A., and Alisch, R. S. (2016). New hope: The emerging role of 5-hydroxymethylcytosine in mental health and disease. Epigenomics 8, 981-991. doi: 10.2217/epi-2016-0020

Magnani, L. (2014). Epigenetic engineering and the art of epigenetic manipulation. Genome Biol. 15:306. doi: 10.1186/gb4179

Maiti, A., and Drohat, A. C. (2011). Thymine DNA glycosylase can rapidly excise 5-formylcytosine and 5-carboxylcytosine: POTENTIAL IMPLICATIONS FOR ACTIVE DEMETHYLATION OF CpG SITES. J. Biol. Chem. 286, 35334-35338. doi: 10.1074/jbc.C111.284620

Marina, R. J., Sturgill, D., Bailly, M. A., Thenoz, M., Varma, G., Prigge, M. F., et al. (2016). TET-catalyzed oxidation of intragenic 5-methylcytosine regulates CTCF-dependent alternative splicing. EMBO J. 35, 335-355. doi: $10.15252 /$ embj.201593235

Masala, L., Burrai, G. P., Bellu, E., Ariu, F., Bogliolo, L., Ledda, S., et al. (2017). Methylation dynamics during folliculogenesis and early embryo development in sheep. Reproduction. 153, 605-619. doi: 10.1530/REP-16-0644

Maurano, M. T., Wang, H., John, S., Shafer, A., Canfield, T., Lee, K., et al. (2015). Role of DNA methylation in modulating transcription factor occupancy. Cell Rep. 12, 1184-1195. doi: 10.1016/j.celrep.2015.07.024

Mayer, W., Niveleau, A., Walter, J., Fundele, R., and Haaf, T. (2000). Embryogenesis: demethylation of the zygotic paternal genome. Nature 403, 501-502. doi: 10.1038/35000656 
Mellén, M., Ayata, P., Dewell, S., Kriaucionis, S., and Heintz, N. (2012). $\mathrm{MeCP} 2$ binds to $5 \mathrm{hmc}$ enriched within active genes and accessible chromatin in the nervous system. Cell 151, 1417-1430. doi: 10.1016/j.cell.2012. 11.022

Messer, W., and Noyer-Weidner, M. (1988). Timing and targeting: the biological functions of Dam methylation in E. coli. Cell 54, 735-737. doi: 10.1016/S0092-8674(88)90911-7

Messerschmidt, D. M. (2012). Should I stay or should I go: Protection and maintenance of DNA methylation at imprinted genes. Epigenetics 7, 969-975. doi: 10.4161 /epi.21337

Mondo, S. J., Dannebaum, R. O., Kuo, R. C., Louie, K. B., Bewick, A. J., LaButti, K., et al. (2017). Widespread adenine N6-methylation of active genes in fungi. Nat. Genet. 49, 964-968. doi: 10.1038/ng.3859

Monk, D. (2015). Germline-derived DNA methylation and early embryo epigenetic reprogramming: The selected survival of imprints. Int. J. Biochem. Cell Biol. 67, 128-138. doi: 10.1016/j.biocel.2015.04.014

Mooijman, D., Dey, S. S., Boisset, J.-C., Crosetto, N., and van Oudenaarden, A. (2016). Single-cell $5 \mathrm{hmC}$ sequencing reveals chromosome-wide cell-tocell variability and enables lineage reconstruction. Nat Biotech 34, 852-856. doi: 10.1038/nbt.3598

Nabel, C. S., Jia, H. J., Ye, Y., Shen, L., Goldschmidt, H. L., Stivers, J. T., et al. (2012). AID/APOBEC deaminases disfavor modified cytosines implicated in DNA demethylation. Nat. Chem. Biol. 8, 751-758. doi: 10.1038/nchembio.1042

Nakamura, T., Arai, Y., Umehara, H., Masuhara, M., Kimura, T., Taniguchi, H., et al. (2007). PGC7/Stella protects against DNA demethylation in early embryogenesis. Nat. Cell Biol. 9, 64-71. doi: 10.1038/ncb1519

Nakamura, T., Liu, Y. J., Nakashima, H., Umehara, H., Inoue, K., Matoba, S., et al. (2012). PGC7 binds histone $\mathrm{H} 3 \mathrm{~K} 9 \mathrm{me} 2$ to protect against conversion of $5 \mathrm{mC}$ to 5 hmC in early embryos. Nature 486, 415-419. doi: 10.1038/nature11093

Neri, F., Incarnato, D., Krepelova, A., Parlato, C., and Oliviero, S. (2016). Methylation-assisted bisulfite sequencing to simultaneously map $5 \mathrm{fC}$ and $5 \mathrm{caC}$ on a genome-wide scale for DNA demethylation analysis. Nat. Protocols 11, 1191-1205. doi: 10.1038/nprot.2016.063

Neri, F., Incarnato, D., Krepelova, A., Rapelli, S., Pagnani, A., Zecchina, R., et al. (2013). Genome-wide analysis identifies a functional association of Tet1 and Polycomb repressive complex 2 in mouse embryonic stem cells. Genome Biol. 14, R91. doi: 10.1186/gb-2013-14-8-r91

Nestler, E. J., Peña, C. J., Kundakovic, M., Mitchell, A., and Akbarian, S. (2016). Epigenetic basis of mental illness. Neuroscientist 22, 447-463. doi: $10.1177 / 1073858415608147$

Nestor, C. E., Ottaviano, R., Reddington, J., Sproul, D., Reinhardt, D., Dunican, D., et al. (2012). Tissue type is a major modifier of the 5-hydroxymethylcytosine content of human genes. Genome Res. 22, 467-477. doi: 10.1101/gr.126417.111

Ngo, T. T. M., Yoo, J., Dai, Q., Zhang, Q., He, C., Aksimentiev, A., et al. (2016). Effects of cytosine modifications on DNA flexibility and nucleosome mechanical stability. Nat. Commun. 7:10813. doi: 10.1038/ncomms10813

Ngo, T. T. M., Zhang, Q., Zhou, R., Yodh, J. G., and Ha, T. (2015). Asymmetric unwrapping of nucleosomes under tension directed by DNA local flexibility. Cell 160, 1135-1144. doi: 10.1016/j.cell.2015.02.001

Nilsson, E. E., and Skinner, M. K. (2015). Environmentally induced epigenetic transgenerational inheritance of Reproductive disease. Biol. Reprod. 93, 8. doi: 10.1095/biolreprod.115.134817

Nordstrand, L. M., Svärd, J., Larsen, E., Nilsen, A., Ougland, R., Furu, K., et al. (2010). Mice lacking Alkbh1 display Sex-Ratio distortion and unilateral eye defects. PLoS ONE 5:e13827. doi: 10.1371/journal.pone.0013827

O’Brown, Z. K., and Greer, E. L. (2016). N6-methyladenine: a conserved and dynamic DNA mark. Adv. Exp. Med. Biol. 945, 213-246. doi: 10.1007/978-3-319-43624-1_10

Okamoto, Y., Yoshida, N., Suzuki, T., Shimozawa, N., Asami, M., Matsuda, T., et al. (2016). DNA methylation dynamics in mouse preimplantation embryos revealed by mass spectrometry. Sci. Rep. 6:19134. doi: 10.1038/srep19134

Okano, M., Bell, D. W., Haber, D. A., and Li, E. (1999). DNA Methyltransferases Dnmt3a and Dnmt3b are essential for De Novo methylation and mammalian development. Cell 99, 247-257. doi: 10.1016/S0092-8674(00)81656-6

Olinski, R., Starczak, M., and Gackowski, D. (2016). Enigmatic 5hydroxymethyluracil: Oxidatively modified base, epigenetic mark or both? Mutat. Res. Rev. Mutat. Res. 767, 59-66. doi: 10.1016/j.mrrev.2016.02.001
O'Neill, C. (2013). Lessons from zebrafish on reprogramming the epigenetic code after fertilisation. Asian J. Androl. 15, 582-583. doi: 10.1038/aja.2013.91

Ooi, S. K. T., Qiu, C., Bernstein, E., Li, K., Jia, D., Yang, Z., et al. (2007). DNMT3L connects unmethylated lysine 4 of histone $\mathrm{H} 3$ to de novo methylation of DNA. Nature 448, 714-717. doi: 10.1038/nature05987

Oswald, J., Engemann, S., Lane, N., Mayer, W., Olek, A., Fundele, R., et al. (2000). Active demethylation of the paternal genome in the mouse zygote. Curr. Biol. 10, 475-478. doi: 10.1016/S0960-9822(00)00448-6

Pan, Z., Sikandar, S., Witherspoon, M., Dizon, D., Nguyen, T., Benirschke, K., et al. (2008). Impaired placental trophoblast lineage differentiation in Alkbh1 $1^{--/--}$ mice. Dev. Dyn. 237, 316-327. doi: 10.1002/dvdy.21418

Papale, L. A., Zhang, Q., Li, S., Chen, K., Keleş, S., and Alisch, R. S. (2015). Genomewide disruption of 5-hydroxymethylcytosine in a mouse model of autism. Hum. Mol. Genet. 24, 7121-7131. doi: 10.1093/hmg/ddv411

Pastor, W. A., Pape, U. J., Huang, Y., Henderson, H. R., Lister, R., Ko, M., et al. (2011). Genome-wide mapping of 5-hydroxymethylcytosine in embryonic stem cells. Nature 473, 394-397. doi: 10.1038/nature10102

Patil, V., Ward, R. L., and Hesson, L. B. (2014). The evidence for functional non-CpG methylation in mammalian cells. Epigenetics 9, 823-828. doi: 10.4161/epi.28741

Peters, J. P., and Maher, L. J. (2010). DNA curvature and flexibility in vitro and in vivo. Q. Rev. Biophys. 43, 23-63. doi: 10.1017/S0033583510000077

Petrussa, L., Van de Velde, H., and De Rycke, M. (2016). Similar kinetics for 5methylcytosine and 5-hydroxymethylcytosine during human preimplantation development in vitro. Mol. Reprod. Dev. 83, 594-605. doi: 10.1002/mrd.22656

Petterson, A., Chung, T. H., Tan, D., Sun, X., and Jia, X. Y. (2014). RRHP: a tagbased approach for 5-hydroxymethylcytosine mapping at single-site resolution. Genome Biol. 15, 456. doi: 10.1186/s13059-014-0456-5

Pfaffeneder, T., Hackner, B., Truß, M., Münzel, M., Müller, M., Deiml, C. A., et al. (2011). The discovery of 5-formylcytosine in embryonic stem cell DNA. Angew. Chem. Int. Ed. Engl. 50, 7008-7012. doi: 10.1002/anie.201103899

Pfaffeneder, T., Spada, F., Wagner, M., Brandmayr, C., Laube, S. K., Eisen, D., et al. (2014). Tet oxidizes thymine to 5-hydroxymethyluracil in mouse embryonic stem cell DNA. Nat. Chem. Biol. 10, 574-581. doi: 10.1038/nchembio.1532

Pfeifer, G. P., Xiong, W., Hahn, M. A., and Jin, S. G. (2014). The role of 5-hydroxymethylcytosine in human cancer. Cell Tissue Res. 356, 631-641. doi: 10.1007/s00441-014-1896-7

Piccolo, F. M., Bagci, H., Brown, K. E., Landeira, D., Soza-Ried, J., Feytout, A., et al. (2013). Different roles for Tet1 and Tet 2 proteins in reprogrammingmediated erasure of imprints induced by egc fusion. Mol. Cell 49, 1023-1033. doi: 10.1016/j.molcel.2013.01.032

Pinney, S. E. (2014). Mammalian Non-CpG methylation: stem cells and beyond. Biology (Basel) 3, 739-751. doi: 10.3390/biology3040739

Plongthongkum, N., Diep, D. H., and Zhang, K. (2014). Advances in the profiling of DNA modifications: cytosine methylation and beyond. Nat. Rev. Genet. 15, 647-661. doi: 10.1038/nrg3772

Ponnaluri, V. K. C., Ehrlich, K. C., Zhang, G., Lacey, M., Johnston, D., Pradhan, S., et al. (2017). Association of 5-hydroxymethylation and 5-methylation of DNA cytosine with tissue-specific gene expression. Epigenetics 12, 123-138. doi: 10.1080/15592294.2016.1265713

Potok, M. E., Nix, D. A., Parnell, T. J., and Cairns, B. R. (2013). Reprogramming the maternal zebrafish genome after fertilization to match the paternal methylation pattern. Cell 153, 759-772. doi: 10.1016/j.cell.2013.04.030

Quenneville, S., Verde, G., Corsinotti, A., Kapopoulou, A., Jakobsson, J., Offner, S., et al. (2011). In embryonic stem cells, ZFP57/KAP1 recognize a methylated hexanucleotide to affect chromatin and DNA methylation of imprinting control regions. Mol. Cell 44, 361-372. doi: 10.1016/j.molcel.2011.08.032

Raiber, E. A., Murat, P., Chirgadze, D. Y., Beraldi, D., Luisi, B. F., and Balasubramanian, S. (2015). 5-Formylcytosine alters the structure of the DNA double helix. Nat. Struct. Mol. Biol. 22, 44-49. doi: 10.1038/nsmb.2936

Ramsahoye, B. H., Biniszkiewicz, D., Lyko, F., Clark, V., Bird, A. P., and Jaenisch, R. (2000). Non-CpG methylation is prevalent in embryonic stem cells and may be mediated by DNA methyltransferase 3a. Proc. Natl. Acad. Sci. U.S.A. 97, 5237-5242. doi: 10.1073/pnas.97.10.5237

Rand, A. C., Jain, M., Eizenga, J. M., Musselman-Brown, A., Olsen, H. E., Akeson, M., et al. (2017). Mapping DNA methylation with high-throughput nanopore sequencing. Nat. Meth 14, 411-413. doi: 10.1038/nmeth.4189 
Rangam, G., Schmitz, K. M., Cobb, A. J. A., and Petersen-Mahrt, S. K. (2012). AID enzymatic activity is inversely proportional to the size of cytosine C5 orbital cloud. PLoS ONE 7:e43279. doi: 10.1371/journal.pone.0043279

Rasmussen, K. D., and Helin, K. (2016). Role of TET enzymes in DNA methylation, development, and cancer. Genes Dev. 30, 733-750. doi: 10.1101/gad.276568.115

Ratnam, S., Mertineit, C., Ding, F., Howell, C. Y., Clarke, H. J., Bestor, T. H., et al. (2002). Dynamics of Dnmt1 methyltransferase expression and intracellular localization during oogenesis and preimplantation development. Dev. Biol. 245, 304-314. doi: 10.1006/dbio.2002.0628

Reynolds, D., Cliffe, L., Förstner, K. U., Hon, C. C., Siegel, T. N., and Sabatini, R. (2014). Regulation of transcription termination by glucosylated hydroxymethyluracil, base J, in Leishmania major and Trypanosoma brucei. Nucleic Acids Res. 42, 9717-9729. doi: 10.1093/nar/gku714

Rhoads, A., and Au, K. F. (2015). PacBio sequencing and its applications. Genomics Proteomics Bioinformatics 13, 278-289. doi: 10.1016/j.gpb.2015.08.002

Riggs, A. D. (1975). X inactivation, differentiation, and DNA methylation. Cytogenet. Cell Genet. 14, 9-25. doi: 10.1159/000130315

Robertson, A. B., Dahl, J. A., and Klungland, A. (2014). DNA metabolism: bases of DNA repair and regulation. Nat. Chem. Biol. 10, 487-488. doi: 10.1038/nchembio. 1553

Robertson, K. D. (2005). DNA methylation and human disease. Nat. Rev. Genet. 6 , 597-610. doi: 10.1038/nrg1655

Rodgers, A. B., Morgan, C. P., Leu, N. A., and Bale, T. L. (2015). Transgenerational epigenetic programming via sperm microRNA recapitulates effects of paternal stress. Proc. Natl. Acad. Sci. U.S.A. 112, 13699-13704. doi: $10.1073 /$ pnas. 1508347112

Ronkainen, J., Huusko, T. J., Soininen, R., Mondini, E., Cinti, F., Mäkelä, K. A., et al. (2015). Fat mass- and obesity-associated gene Fto affects the dietary response in mouse white adipose tissue. Sci. Rep. 5:9233. doi: 10.1038/srep09233

Rose, N. R., and Klose, R. J. (2014). Understanding the relationship between DNA methylation and histone lysine methylation. Biochim. Biophys. Acta 1839, 1362-1372. doi: 10.1016/j.bbagrm.2014.02.007

Ruzov, A., Tsenkina, Y., Serio, A., Dudnakova, T., Fletcher, J., Bai, Y., et al. (2011). Lineage-specific distribution of high levels of genomic 5hydroxymethylcytosine in mammalian development. Cell Res. 21, 1332-1342. doi: $10.1038 /$ cr.2011.113

Sager, R., and Kitchin, R. (1975). Selective silencing of eukaryotic DNA. Science $189,426-433$.

Salvaing, J., Aguirre-Lavin, T., Boulesteix, C., Lehmann, G., Debey, P., and Beaujean, N. (2012). 5-Methylcytosine and 5-Hydroxymethylcytosine Spatiotemporal Profiles in the Mouse Zygote. PLoS ONE 7:e38156. doi: 10.1371/journal.pone.0038156

Sampath Kumar, A., Seah, M. K., Ling, K. Y., Wang, Y., Tan, J. H., Nitsch, S., et al. (2017). Loss of maternal Trim 28 causes male-predominant early embryonic lethality. Genes Dev. 31, 12-17. doi: 10.1101/gad.291195.116

Sarnacki, S. H., Castañeda, M.,d,.R. A., Llana, M. N., Giacomodonato, M. N., Valvano M. Á., and Cerquetti, M. C. (2013). Dam methylation participates in the regulation of PmrA/PmrB and $\mathrm{RcsC} / \mathrm{RcsD} / \mathrm{RcsB}$ two component regulatory systems in salmonella enterica serovar enteritidis. PLOS ONE 8:e56474. doi: 10.1371/journal.pone.0056474

Sasaki, K., Nakamura, T., Okamoto, K., Yabuta, Y., Iwatani, C., Tsuchiya, H., et al. (2016). The germ cell fate of cynomolgus monkeys is specified in the nascent amnion. Dev. Cell 39, 169-185. doi: 10.1016/j.devcel.2016.09.007

Schaefer, M., Pollex, T., Hanna, K., Tuorto, F., Meusburger, M., Helm, M., et al. (2010). RNA methylation by Dnmt2 protects transfer RNAs against stressinduced cleavage. Genes Dev. 24, 1590-1595. doi: 10.1101/gad.586710

Schiffers, S., Ebert, C., Rahimoff, R., Kosmatchev, O., Steinbacher, J., Bohne, A. V., et al. (2017). Quantitative LC-MS provides no evidence for m6dA or m4dC in the genome of mouse embryonic stem cells and tissues. Angew. Chem. Int. Ed. Engl. 56, 11268-11271. doi: 10.1002/anie.201700424

Schultz, M. D., He, Y., Whitaker, J. W., Hariharan, M., Mukamel, E. A., Leung, D., et al. (2015). Human body epigenome maps reveal noncanonical DNA methylation variation. Nature 523, 212-216. doi: 10.1038/nature14465

Schuster, A., Skinner, M. K., and Yan, W. (2016). Ancestral vinclozolin exposure alters the epigenetic transgenerational inheritance of sperm small noncoding RNAs. Environ Epigenet 2:dvw001. doi: 10.1093/eep/dvw001

Seisenberger, S., Andrews, S., Krueger, F., Arand, J., Walter, J., Santos, F., et al. (2012). The dynamics of genome-wide DNA methylation reprogramming in mouse primordial germ cells. Mol. Cell 48, 849-862. doi: 10.1016/j.molcel.2012.11.001

Sharma, U., Conine, C. C., Shea, J. M., Boskovic, A., Derr, A. G., Bing, X. Y., et al. (2016). Biogenesis and function of tRNA fragments during sperm maturation and fertilization in mammals. Science 351, 391-396. doi: 10.1126/science.aad6780

Shen, F., Huang, W., Huang, J.-T., Xiong, J., Yang, Y., Wu, K., et al. (2015). Decreased N6-methyladenosine in peripheral blood RNA from diabetic patients is associated With FTO expression rather than ALKBH5. J. Clin. Endocrinol. Metab. 100, E148-E154. doi: 10.1210/jc.2014-1893

Shen, L., Wu, H., Diep, D., Yamaguchi, S., D’Alessio, A. C., Fung, H. L., et al. (2013). Genome-wide analysis reveals TET- and TDG-dependent 5-methylcytosine oxidation dynamics. Cell 153, 692-706. doi: 10.1016/j.cell.2013.04.002

Shirane, K., Toh, H., Kobayashi, H., Miura, F., Chiba, H., Ito, T., et al. (2013). Mouse oocyte methylomes at base resolution reveal genome-wide accumulation of non-CpG methylation and role of DNA methyltransferases. PLoS Genet. 9:e1003439. doi: 10.1371/journal.pgen.1003439

Simpson, J. T., Workman, R. E., Zuzarte, P. C., David, M., Dursi, L. J., and Timp, W. (2017). Detecting DNA cytosine methylation using nanopore sequencing. Nat. Meth. 14, 407-410. doi: 10.1038/nmeth.4184

Skinner, M. K., Guerrero-Bosagna, C., Haque, M., Nilsson, E., Bhandari, R., and McCarrey, J. R. (2013). Environmentally induced transgenerational epigenetic reprogramming of primordial germ cells and the subsequent germ line. PLoS ONE 8:e66318. doi: 10.1371/annotation/7683bb48-85db-4c7e-87c0-304a7d53a587

Smith, Z. D., Chan, M. M., Humm, K. C., Karnik, R., Mekhoubad, S., Regev, A., et al. (2014). DNA methylation dynamics of the human preimplantation embryo. Nature 511, 611-615. doi: 10.1038/nature13581

Smith, Z. D., Chan, M. M., Mikkelsen, T. S., Gu, H., Gnirke, A., Regev, A., et al. (2012). A unique regulatory phase of DNA methylation in the early mammalian embryo. Nature 484, 339-344. doi: 10.1038/nature 10960

Smith, Z. D., and Meissner, A. (2013). DNA methylation: roles in mammalian development. Nat. Rev. Genet. 14, 204-220. doi: 10.1038/nrg3354

Song, C.-X., Diao, J., Brunger, A. T., and Quake, S. R. (2016). Simultaneous singlemolecule epigenetic imaging of DNA methylation and hydroxymethylation. Proc. Natl. Acad. Sci. U.S.A. 113, 4338-4343. doi: 10.1073/pnas.16002 23113

Song, C. X., Szulwach, K. E., Dai, Q., Fu, Y., Mao, S. Q., Lin, L., et al. (2013). Genome-wide profiling of 5-Formylcytosine reveals its roles in epigenetic priming. Cell 153, 678-691. doi: 10.1016/j.cell.2013.04.001

Song, J., and Pfeifer, G. P. (2016). Are there specific readers of oxidized 5methylcytosine bases? Bioessays 38, 1038-1047. doi: 10.1002/bies.201600126

Sood, A. J., Viner, C., and Hoffman, M. M. (2016). DNAmod: the DNA modification database. bioRxiv. doi: 10.1101/071712

Sperlazza, M. J., Bilinovich, S. M., Sinanan, L. M., Javier, F. R., and Williams, D. C. Jr. (2017). Structural basis of MeCP2 distribution on Non-CpG methylated and hydroxymethylated DNA. J. Mol. Biol. 429, 1581-1594. doi: 10.1016/j.jmb.2017.04.009

Spruijt, C. G., Gnerlich, F., Smits, A. H., Pfaffeneder, T., Jansen, P. W., Bauer, C., et al. (2013). Dynamic readers for 5-(Hydroxy)methylcytosine and its oxidized derivatives. Cell 152, 1146-1159. doi: 10.1016/j.cell.2013. 02.004

Stadler, M. B., Murr, R., Burger, L., Ivanek, R., Lienert, F., Schöler, A., et al. (2011). DNA-binding factors shape the mouse methylome at distal regulatory regions. Nature 480, 490-495. doi: 10.1038/nature10716

Stöger, R., Scaife, P. J., Shephard, F., and Chakrabarti, L. (2017). Elevated 5hmC levels characterize DNA of the cerebellum in Parkinson's disease. Parkinsons Dis. 3, 6. doi: 10.1038/s41531-017-0007-3

Strogantsev, R., Krueger, F., Yamazawa, K., Shi, H., Gould, P., Goldman-Roberts, M., et al. (2015). Allele-specific binding of ZFP57 in the epigenetic regulation of imprinted and non-imprinted monoallelic expression. Genome Biol. 16, 112. doi: 10.1186/s13059-015-0672-7

Stroud, H., Feng, S., Morey Kinney, S., Pradhan, S., and Jacobsen, S. E. (2011). 5Hydroxymethylcytosine is associated with enhancers and gene bodies in human embryonic stem cells. Genome Biol. 12, R54. doi: 10.1186/gb-2011-12-6-r54

Sun, Z. Y., Terragni, J., Borgaro, J. G., Liu, Y. W., Yu, L., Guan, S. X., et al. (2013). High-resolution enzymatic mapping of genomic 5-hydroxymethylcytosine 
in mouse embryonic stem cells (vol 3, pg 567, 2013). Cell Rep. 3, 968. doi: 10.1016/j.celrep.2013.01.001

Szulwach, K. E., Li, X., Li, Y., Song, C. X., Wu, H., Dai, Q., et al. (2011). 5hmCmediated epigenetic dynamics during postnatal neurodevelopment and aging. Nat. Neurosci. 14, 1607-1616. doi: 10.1038/nn.2959

Tan, F. E., and Yeo, G. W. (2016). Blurred boundaries: the RNA binding protein Lin28A is also an epigenetic regulator. Mol. Cell 61, 1-2. doi: 10.1016/j.molcel.2015.12.018

Tang, W. W., Dietmann, S., Irie, N., Leitch, H. G., Floros, V. I., Bradshaw, C. R., et al. (2015). A unique gene regulatory network resets the human germline epigenome for development. Cell 161, 1453-1467. doi: 10.1016/j.cell.2015.04.053

Thakore, P. I., Black, J. B., Hilton, I. B., and Gersbach, C. A. (2016). Editing the epigenome: technologies for programmable transcription and epigenetic modulation. Nat. Meth. 13, 127-137. doi: 10.1038/nmeth .3733

Thiaville, J. J., Kellner, S. M., Yuan, Y., Hutinet, G., Thiaville, P. C., Jumpathong, W., et al. (2016). Novel genomic island modifies DNA with 7-deazaguanine derivatives. Proc. Natl. Acad. Sci. U.S.A. 113, E1452-E1459. doi: $10.1073 /$ pnas. 1518570113

Tomizawa, S. I., Kobayashi, H., Watanabe, T., Andrews, S., Hata, K., Kelsey, G., et al. (2011). Dynamic stage-specific changes in imprinted differentially methylated regions during early mammalian development and prevalence of non-CpG methylation in oocytes. Development 138, 811-820. doi: $10.1242 /$ dev. 061416

Tseng, P.-T., Lin, P.-Y., Lee, Y., Hung, C.-F., Lung, F.-W., Chen, C.S., et al. (2014). Age-associated decrease in global DNA methylation in patients with major depression. Neuropsychiatr. Dis. Treat. 10, 2105-2114. doi: 10.2147/NDT.S71997

Tsukada, Y.-I., Akiyama, T., and Nakayama, K. I. (2015). Maternal TET3 is dispensable for embryonic development but is required for neonatal growth. Sci. Rep. 5:15876. doi: 10.1038/srep15876

Tuorto, F., Liebers, R., Musch, T., Schaefer, M., Hofmann, S., Kellner, S., et al. (2012). RNA cytosine methylation by Dnmt2 and NSun2 promotes tRNA stability and protein synthesis. Nat. Struct. Mol. Biol. 19, 900-905. doi: $10.1038 /$ nsmb. 2357

van Luenen, H. G., Farris, C., Jan, S., Genest, P. A., Tripathi, P., Velds, A., et al. (2012). Glucosylated hydroxymethyluracil, DNA Base J, prevents transcriptional readthrough in leishmania. Cell 150, 909-921. doi: 10.1016/j.cell.2012.07.030

Vanyushin, B. F., and Ashapkin, V. V. (2011). DNA methylation in higher plants: Past, present and future. Biochim. et Biophys. Acta 1809, 360-368. doi: 10.1016/j.bbagrm.2011.04.006

Velasco, G., Hubé, F., Rollin, J., Neuillet, D., Philippe, C., Bouzinba-Segard, H., et al. (2010). Dnmt3b recruitment through E2F6 transcriptional repressor mediates germ-line gene silencing in murine somatic tissues. Proc. Natl. Acad. Sci. U.S.A. 107, 9281-9286. doi: 10.1073/pnas. 1000473107

Vella, P., Scelfo, A., Jammula, S., Chiacchiera, F., Williams, K., Cuomo, A., et al. (2013). Tet proteins connect the O-Linked N-acetylglucosamine transferase Ogt to chromatin in embryonic stem cells. Mol. Cell 49, 645-656. doi: 10.1016/j.molcel.2012.12.019

Vlachogiannis, G., Niederhuth, C. E., Tuna, S., Stathopoulou, A., Viiri, K., de Rooij, D. G., et al. (2015). The Dnmt3L ADD Domain controls cytosine methylation establishment during spermatogenesis. Cell Rep. 10, 944-956. doi: 10.1016/j.celrep.2015.01.021

von Meyenn, F., and Reik, W. (2015). Forget the parents: epigenetic reprogramming in human germ cells. Cell 161, 1248-1251. doi: $10.1016 /$ j.cell.2015.05.039

Vrachnis, N., Antonakopoulos, N., Iliodromiti, Z., Dafopoulos, K., Siristatidis, C., Pappa, K. I., et al. (2012). Impact of maternal diabetes on epigenetic modifications leading to diseases in the offspring. Exp. Diabetes Res. 2012:538474. doi: 10.1155/2012/538474

Wahl, S., Drong, A., Lehne, B., Loh, M., Scott, W. R., Kunze, S., et al. (2017). Epigenome-wide association study of body mass index, and the adverse outcomes of adiposity. Nature 541, 81-86. doi: 10.1038/nature20784

Wang, H., Maurano, M. T., Qu, H., Varley, K. E., Gertz, J., Pauli, F., et al. (2012). Widespread plasticity in CTCF occupancy linked to DNA methylation. Genome Res. 22, 1680-1688. doi: 10.1101/gr.136101.111
Wang, H., Yang, H., Shivalila, C. S., Dawlaty, M. M., Cheng, A. W., Zhang, F., et al. (2013). One-step generation of mice carrying mutations in multiple genes by CRISPR/Cas-mediated genome engineering. Cell 153, 910-918. doi: 10.1016/j.cell.2013.04.025

Wang, L., Zhou, Y., Xu, L., Xiao, R., Lu, X., Chen, L., et al. (2015). Molecular basis for 5-carboxycytosine recognition by RNA polymerase II elongation complex. Nature 523, 621-625. doi: 10.1038/nature14482

Wang, W., Xu, L., Hu, L., Chong, J., He, C., and Wang, D. (2017). Epigenetic DNA modification N6-methyladenine causes site-specific RNA polymerase II transcriptional pausing. J. Am. Chem. Soc. 39, 14436-14442. doi: $10.1021 /$ jacs.7b06381

Wang, Y., Sheng, Y., Liu, Y., Pan, B., Huang, J., Warren, A., et al. (2017). N6-methyladenine DNA modification in the unicellular eukaryotic organism Tetrahymena thermophila. Eur. J. Protistol. 58, 94-102. doi: 10.1016/j.ejop.2016.12.003

Watanabe, D., Suetake, I., Tada, T., and Tajima, S. (2002). Stage- and cell-specific expression of Dnmt3a and Dnmt3b during embryogenesis. Mech. Dev. 118, 187-190. doi: 10.1016/S0925-4773(02)00242-3

Watson, E. D. (2016). Transferring fragments of paternal metabolism to the offspring. Cell Metab. 23, 401-402. doi: 10.1016/j.cmet.2016.02.014

Williams, K., Christensen, J., Pedersen, M. T., Johansen, J. V., Cloos, P. A. C., Rappsilber, J., et al. (2011). TET1 and hydroxymethylcytosine in transcription and DNA methylation fidelity. Nature 473, 343-348. doi: 10.1038/nature10066

Wossidlo, M., Nakamura, T., Lepikhov, K., Marques, C. J., Zakhartchenko, V., Boiani, M., et al. (2011). 5-Hydroxymethylcytosine in the mammalian zygote is linked with epigenetic reprogramming. Nat. Commun. 2, 241. doi: $10.1038 /$ ncomms 1240

Wu, H., D/'Alessio, A. C., Ito, S., Xia, K., Wang, Z., Cui, K., et al. (2011). Dual functions of Tet1 in transcriptional regulation in mouse embryonic stem cells. Nature 473, 389-393. doi: 10.1038/nature09934

$\mathrm{Wu}, \mathrm{H}$., Wu, X., Shen, L., and Zhang, Y. (2014). Single-base resolution analysis of active DNA demethylation using methylase-assisted bisulfite sequencing. Nat. Biotech. 32, 1231-1240. doi: 10.1038/nbt.3073

$\mathrm{Wu}, \mathrm{H}$., and Zhang, Y. (2011). Tetl and 5-hydroxymethylation: A genomewide view in mouse embryonic stem cells. Cell Cycle 10, 2428-2436. doi: $10.4161 /$ cc. 10.15 .16930

$\mathrm{Wu}, \quad \mathrm{H}$. , and Zhang, Y. (2014). Reversing DNA methylation: mechanisms, genomics, and biological functions. Cell 156, 45-68. doi: 10.1016/j.cell.2013.12.019

Wu, T. P., Wang, T., Seetin, M. G., Lai, Y., Zhu, S., Lin, K., et al. (2016). DNA methylation on N6-adenine in mammalian embryonic stem cells. Nature 532, 329-333. doi: 10.1038/nature 17640

Xu, Y., Wu, F., Tan, L., Kong, L., Xiong, L., Deng, J., et al. (2011). Genome-wide regulation of $5 \mathrm{hmC}, 5 \mathrm{mC}$, and gene expression by Tet 1 hydroxylase in mouse embryonic stem cells. Mol. Cell 42, 451-464. doi: 10.1016/j.molcel.2011.04.005

Yamaguchi, S., Hong, K., Liu, R., Inoue, A., Shen, L., Zhang, K., et al. (2013a). Dynamics of 5-methylcytosine and 5-hydroxymethylcytosine during germ cell reprogramming. Cell Res. 23, 329-339. doi: 10.1038/cr.2013.22

Yamaguchi, S., Hong, K., Liu, R., Shen, L., Inoue, A., Diep, D., et al. (2012). Tet1 controls meiosis by regulating meiotic gene expression. Nature 492, 443-447. doi: 10.1038/nature11709

Yamaguchi, S., Shen, L., Liu, Y., Sendler, D., and Zhang, Y. (2013b). Role of Tet1 in erasure of genomic imprinting. Nature 504, 460-464. doi: 10.1038/nature12805

Yang, H., Liu, Y., Bai, F., Zhang, J. Y., Ma, S. H., Liu, J., et al. (2013). Tumor development is associated with decrease of TET gene expression and 5methylcytosine hydroxylation. Oncogene 32, 663-669. doi: 10.1038/onc.20 12.67

Yildirim, O., Li, R., Hung, J.-H., Chen, P. B., Dong, X., Ee, L.-S., et al. (2011). Mbd3/NURD complex regulates expression of 5hydroxymethylcytosine marked genes in embryonic stem cells. Cell 147, 1498-1510. doi: 10.1016/j.cell.2011.11.054

Yu, M., Hon, G. C., Szulwach, K. E., Song, C.-X., Zhang, L., Kim, A., et al. (2012). Base-Resolution Analysis of 5-Hydroxymethylcytosine in the Mammalian Genome. Cell 149, 1368-1380. doi: 10.1016/j.cell.2012.04.027

Zaleski, P., Wojciechowski, M., and Piekarowicz, A. (2005). The role of Dam methylation in phase variation of Haemophilus influenzae genes involved in defence against phage infection. Microbiology 151, 3361-3369. doi: $10.1099 /$ mic.0.28184-0 
Zeng, Y. X., Yao, B., Shin, J., Lin, L., Kim, N., Song, Q. F., et al. (2016). Lin28A binds active promoters and recruits Tet1 to regulate gene expression. Mol. Cell 61, 153-160. doi: 10.1016/j.molcel.2015.11.020

Zhang, D., Wu, B., Wang, P., Wang, Y., Lu, P., Nechiporuk, T., et al. (2017). Non-CpG methylation by DNMT3B facilitates REST binding and gene silencing in developing mouse hearts. Nucleic Acids Res. 45, 3102-3115. doi: 10.1093/nar/gkw1258

Zhang, G., Huang, H., Liu, D., Cheng, Y., Liu, X., Zhang, W., et al. (2015). N6-methyladenine DNA modification in drosophila. Cell 161, 893-906. doi: 10.1016/j.cell.2015.04.018

Zhang, H. Y., Xiong, J., Qi, B. L., Feng, Y. Q., and Yuan, B. F. (2016). The existence of 5-hydroxymethylcytosine and 5-formylcytosine in both DNA and RNA in mammals. Chem. Commun. 52, 737-740. doi: 10.1039/c5cc0 $7354 \mathrm{e}$

Zhang, S., Chen, X., Wang, F., An, X., Tang, B., Zhang, X., et al. (2016). Aberrant DNA methylation reprogramming in bovine SCNT preimplantation embryos. Sci. Rep. 6:30345. doi: 10.1038/srep30345

Zhang, X., Su, J., Jeong, M., Ko, M., Huang, Y., Park, H. J., et al. (2016). DNMT3A and TET2 compete and cooperate to repress lineage-specific transcription factors in hematopoietic stem cells. Nat. Genet. 48, 1014-1023. doi: $10.1038 /$ ng.3610

Zhao, L., Sun, M. A., Li, Z., Bai, X., Yu, M., Wang, M., et al. (2014). The dynamics of DNA methylation fidelity during mouse embryonic stem cell self-renewal and differentiation. Genome Res. 24, 1296-1307. doi: 10.1101/gr.163147.113
Zhou, T., Xiong, J., Wang, M., Yang, N., Wong, J., Zhu, B., et al. (2014). Structural basis for hydroxymethylcytosine recognition by the SRA domain of UHRF2. Mol. Cell 54, 879-886. doi: 10.1016/j.molcel.2014.04.003

Zhu, C., Gao, Y., Guo, H., Xia, B., Song, J., Wu, X., et al. (2017). Single-Cell 5-formylcytosine landscapes of mammalian early embryos and ESCs at single-base resolution. Cell Stem Cell 20, 720 e725-731 e725. doi: 10.1016/j.stem.2017.02.013

Zhu, P., Guo, H., Ren, Y., Hou, Y., Dong, J., Li, R., et al. (2018). Single-cell DNA methylome sequencing of human preimplantation embryos. Nat. Genet. 50 12-19. doi: 10.1038/s41588-017-0007-6

Ziller, M. J., Müller, F., Liao, J., Zhang, Y., Gu, H., Bock, C., et al. (2011). Genomic distribution and inter-sample variation of non-CpG methylation across human cell types. PLoS Genet. 7:e1002389. doi: 10.1371/journal.pgen.1002389

Conflict of Interest Statement: The authors declare that the research was conducted in the absence of any commercial or financial relationships that could be construed as a potential conflict of interest.

Copyright (C) $2018 \mathrm{Zhu}$, Stöger and Alberio. This is an open-access article distributed under the terms of the Creative Commons Attribution License (CC BY). The use, distribution or reproduction in other forums is permitted, provided the original author(s) and the copyright owner are credited and that the original publication in this journal is cited, in accordance with accepted academic practice. No use, distribution or reproduction is permitted which does not comply with these terms. 